\title{
Review Article \\ Organ-Protective Effects of Red Wine Extract, Resveratrol, in Oxidative Stress-Mediated Reperfusion Injury
}

\author{
Fu-Chao Liu,, ${ }^{1,2}$ Hsin-I Tsai, ${ }^{1,2}$ and Huang-Ping Yu ${ }^{1,2}$ \\ ${ }^{1}$ Department of Anesthesiology, Chang Gung Memorial Hospital, 5 Fu-Shin Street, Kwei-Shan, Taoyuan 333, Taiwan \\ ${ }^{2}$ College of Medicine, Chang Gung University, Taoyuan, Taiwan \\ Correspondence should be addressed to Huang-Ping Yu; yuhp2001@adm.cgmh.org.tw
}

Received 10 September 2014; Accepted 9 October 2014

Academic Editor: Zhengyuan Xia

Copyright (c) $2015 \mathrm{Fu}-\mathrm{Chao}$ Liu et al. This is an open access article distributed under the Creative Commons Attribution License, which permits unrestricted use, distribution, and reproduction in any medium, provided the original work is properly cited.

\begin{abstract}
Resveratrol, a polyphenol extracted from red wine, possesses potential antioxidative and anti-inflammatory effects, including the reduction of free radicals and proinflammatory mediators overproduction, the alteration of the expression of adhesion molecules, and the inhibition of neutrophil function. A growing body of evidence indicates that resveratrol plays an important role in reducing organ damage following ischemia- and hemorrhage-induced reperfusion injury. Such protective phenomenon is reported to be implicated in decreasing the formation and reaction of reactive oxygen species and pro-nflammatory cytokines, as well as the mediation of a variety of intracellular signaling pathways, including the nitric oxide synthase, nicotinamide adenine dinucleotide phosphate oxidase, deacetylase sirtuin 1, mitogen-activated protein kinase, peroxisome proliferator-activated receptor-gamma coactivator 1 alpha, hemeoxygenase-1, and estrogen receptor-related pathways. Reperfusion injury is a complex pathophysiological process that involves multiple factors and pathways. The resveratrol is an effective reactive oxygen species scavenger that exhibits an antioxidative property. In this review, the organ-protective effects of resveratrol in oxidative stress-related reperfusion injury will be discussed.
\end{abstract}

\section{Introduction}

Resveratrol, found in various plants, nuts, and fruits and especially abundant in grapes and red wine, is a naturally occurring plant antibiotic known as phytoalexins $[1,2]$. Previous reports have demonstrated the protective effects of resveratrol in different pathological models and experimental conditions [3-6]. Many clinical studies indicate the beneficial effects of resveratrol in human diseases [7-12]. Recent report indicates that intake of a McDonald's meal with red wine could decrease oxidized low density lipoprotein level and increase antioxidative gene expression in healthy human [13]. A growing body of evidence indicates that resveratrol may play potential therapeutic roles in human health by its antioxidant, anti-inflammatory, antiaging, antidiabetic, and apoptotic properties [12, 14-17]. A number of target molecules mediating the abovementioned protective effects of resveratrol have been identified, including the endothelial nitric oxide synthase (eNOS) $[18,19]$, the mitogen-activated protein kinase (MAPK) [20, 21], the hemeoxygenase-1 (HO1) [3], the estrogen receptor (ER) $[20,22-24]$, the histone deacetylase sirtuin 1 (SIRT1) [25-28], the nuclear factor E2-related factor-2 (Nfr2) $[3,29]$, and nuclear factor-kappa $\mathrm{B}(\mathrm{NF}-\kappa \mathrm{B})[30,31]$. A variety of laboratory and clinical studies also indicate that resveratrol may lead to tissue and organ protective effects against various injuries $[6,19,32-$ 35]. Ischemia-reperfusion (I/R) injury induces free radical formation and inflammation within hours and results in the excessive production of oxidants and proinflammatory mediators and that play a significant role in the development of multiple organ dysfunctions under those conditions [3638]. Resveratrol has been suggested as an organ-protective agent to prevent and treat ischemia and shock-like and reperfusion injury due to its antioxidative activities [20, 3949]. In this review, we summarize the protective effects and possible mechanisms of resveratrol on the preservation of organ function in oxidative stress-mediated I/R injury (Table 1). 
TABLE 1: Protective effects and mechanisms of the resveratrol on different organs in oxidative stress-mediated reperfusion injury.

\begin{tabular}{|c|c|c|c|c|}
\hline Species/targets & Model of reperfusion injury & Effective dose & $\begin{array}{c}\text { Effects and } \\
\text { mechanisms }\end{array}$ & References \\
\hline $\begin{array}{l}\text { Male Wistar rats } \\
\text { rat/heart }\end{array}$ & $\begin{array}{c}\text { Langendorff-perfused mode } \\
\text { (ischemia } 45 \mathrm{~min} \text {, reperfusion } 10 \mathrm{~min} \text { ). }\end{array}$ & $\begin{array}{c}25 \mathrm{mg} / \mathrm{kg} \\
\text { (pretreatment } 7 \text { days, IP) }\end{array}$ & $\begin{array}{c}\text { MDA } \downarrow, \mathrm{CAT} \downarrow \text {, } \\
\text { peroxidase } \uparrow \text {, and } \\
\text { SOD } \uparrow\end{array}$ & {$[80]$} \\
\hline $\begin{array}{l}\text { Spraque-Dawley } \\
\text { rats/heart }\end{array}$ & $\begin{array}{l}\text { Langendorff-perfused mode } \\
\text { (ischemia } 60 \mathrm{~min} \text {, reperfusion } 60 \mathrm{~min} \text { ) }\end{array}$ & $\begin{array}{c}20 \mathrm{mg} / \mathrm{kg} \\
\text { (pretreatment } 14 \text { days } \\
\text { intragastric tube), } \\
10 \mu \mathrm{M} \text { (30 min before ischemia) }\end{array}$ & $\begin{array}{c}\mathrm{MDA} \downarrow, \mathrm{LDH} \downarrow \\
\text { carbonyl } \downarrow \text {, and GSH } \uparrow\end{array}$ & {$[68]$} \\
\hline $\begin{array}{l}\text { Male Sprague-Dawley } \\
\text { rats/heart }\end{array}$ & $\begin{array}{l}\text { Langendorff-perfused mode } \\
\text { (ischemia } 30 \mathrm{~min} \text {, reperfusion } 2 \mathrm{~h} \text { ) }\end{array}$ & $\begin{array}{c}10 \mu \mathrm{M} \\
(30 \text { min before ischemia, IV } \\
\text { perfused) }\end{array}$ & $\begin{array}{l}\text { MDA } \downarrow \text { and infarct } \\
\text { volume } \downarrow\end{array}$ & {$[49]$} \\
\hline $\begin{array}{l}\text { Male Sprague Dawley } \\
\text { rats/heart }\end{array}$ & $\begin{array}{c}\text { Langendorff-perfused mode } \\
\text { (ischemia } 15 \mathrm{~min} \text {, reperfusion } 10 \mathrm{~min} \text { ). }\end{array}$ & $\begin{array}{c}\text { resveratrol } \\
1-100 \mu \mathrm{M} \text { (pretreatment } 7 \text { days, } \\
\text { IP) }\end{array}$ & $\begin{array}{l}\mathrm{MDA} \downarrow \text { and no } \\
\text { improvement in heart } \\
\text { function }\end{array}$ & {$[82]$} \\
\hline Sprague-Dawley/Brain & $\begin{array}{l}\text { Right middle cerebral artery occlusion } \\
\text { (ischemia } 30 \mathrm{~min} \text {, reperfusion } 5.5 \mathrm{~h} \text { ) }\end{array}$ & $\begin{array}{c}0.1-1.0 \mu \mathrm{M} \\
(10 \mathrm{~min} \text { before ischemia, IV) }\end{array}$ & $\begin{array}{l}\text { Activation of ER- } \alpha \\
\text { and ER- } \beta \text { and infarct } \\
\text { volume } \downarrow\end{array}$ & {$[23]$} \\
\hline Male Wistar rats/brain & $\begin{array}{l}\text { Bilateral common carotid occlusion } \\
\text { (occlusion } 4 \mathrm{~h})\end{array}$ & $\begin{array}{c}5-30 \mathrm{mg} / \mathrm{kg} \\
(5 \mathrm{~min} \text { before reperfusion, IP) }\end{array}$ & $\begin{array}{c}\text { MDA } \downarrow, \text { MPO } \downarrow \text {, } \\
\text { TNF- } \alpha \downarrow \text {, IL-6 } \downarrow \text {, } \\
\text { ICAM-I } \downarrow \text {, Catalase } \uparrow \text {, } \\
\text { SOD } \uparrow, \text { and IL-10 } \uparrow\end{array}$ & {$[99]$} \\
\hline $\begin{array}{l}\text { Male Sprague-Dawley } \\
\text { rats/brain }\end{array}$ & $\begin{array}{l}\text { Middle cerebral artery occlusion. } \\
\text { (occlusion } 2 \mathrm{~h} \text { ) }\end{array}$ & $\begin{array}{c}30 \mathrm{mg} / \mathrm{kg} \\
\text { (pretreatment } 7 \text { days, IP) }\end{array}$ & $\begin{array}{c}\text { Adesonine } \uparrow \text {, inosine } \uparrow \text {, } \\
\text { hypoxanthine } \downarrow \text {, and } \\
\text { xanthine } \downarrow\end{array}$ & {$[92]$} \\
\hline Male Wistar rats/Brain & $\begin{array}{l}\text { Bilateral common carotid occlusion } \\
\text { (occlusion } 10 \mathrm{~min} \text { ) }\end{array}$ & $\begin{array}{c}30 \mathrm{mg} / \mathrm{kg} \\
\text { (pretreatment } 7 \text { days, IP) }\end{array}$ & $\begin{array}{l}\mathrm{ROS} \downarrow, \mathrm{MDA} \downarrow, \mathrm{NO} \downarrow \\
\text { and } \mathrm{Na}^{+} \mathrm{K}^{+} \text {-aTPase } \downarrow\end{array}$ & {$[61]$} \\
\hline Male Wistar rats/brain & $\begin{array}{l}\text { Bilateral common carotid occlusion } \\
\text { (occlusion } 10 \mathrm{~min} \text { ) }\end{array}$ & $\begin{array}{c}30 \mathrm{mg} / \mathrm{kg} \\
\text { (pretreatment } 7 \text { days, IP) }\end{array}$ & $\begin{array}{c}\text { COX }-2 \downarrow \text { and iNOS } \downarrow \\
\text { and NF-kB and JNK } \\
\text { activation } \downarrow\end{array}$ & {$[100]$} \\
\hline $\begin{array}{l}\text { Male Sprague-Dawley } \\
\text { rats/brain }\end{array}$ & $\begin{array}{l}\text { Middle cerebral artery occlusion } \\
\text { (occlusion } 30 \mathrm{~min} \text { ) }\end{array}$ & $\begin{array}{l}15 \text { and } 30 \mathrm{mg} / \mathrm{kg} \\
\text { (pretreatment } 7 \text { days, IP) }\end{array}$ & $\begin{array}{c}\mathrm{MDA} \downarrow, \mathrm{SOD} \uparrow, \mathrm{Nrf} 2 \uparrow \\
\mathrm{HO}-1 \uparrow \text {, and } \\
\text { caspase- } 3 \downarrow\end{array}$ & {$[3]$} \\
\hline Mongolian gerbils/brain & $\begin{array}{l}\text { Bilateral common carotid occlusion } \\
\text { (occlusion } 5 \mathrm{~min} \text { ) }\end{array}$ & $\begin{array}{c}30 \mathrm{mg} / \mathrm{kg} \\
\text { (during occlusion, IP) }\end{array}$ & Neuronal cell death $\downarrow$ & {$[48]$} \\
\hline Male Wistar rats/Brain & $\begin{array}{l}\text { Middle cerebral artery occlusion } \\
\text { (occlusion } 2 \mathrm{~h})\end{array}$ & $\begin{array}{l}20 \mathrm{mg} / \mathrm{kg} \\
\text { (pretreatment } 21 \text { days, IP) }\end{array}$ & $\begin{array}{l}\text { MDA } \downarrow, \mathrm{GSH} \uparrow \text {, and } \\
\text { infarct volume and } \\
\text { motor impairment } \downarrow\end{array}$ & {$[96]$} \\
\hline $\begin{array}{l}\text { Male New Zealand white } \\
\text { rabbits/spinal cord }\end{array}$ & $\begin{array}{l}\text { Occlusion of the infrarenal aorta } \\
\text { (ischemia } 30 \mathrm{~min} \text { ) }\end{array}$ & $\begin{array}{c}1-10 \mathrm{mg} / \mathrm{kg} \\
\text { (pretreatment } 30 \text { minutes, IV) }\end{array}$ & $\mathrm{MDA} \downarrow$ and $\mathrm{NO} \uparrow$ & {$[101]$} \\
\hline $\begin{array}{l}\text { Male New Zealand white } \\
\text { rabbits/spinal cord }\end{array}$ & $\begin{array}{l}\text { Abdominal aorta clamp } \\
\text { (ischemia } 30 \text { minute) }\end{array}$ & $\begin{array}{l}100 \mu \mathrm{g} / \mathrm{kg} \\
\text { (pretreatment } 15 \text { minutes before } \\
\text { occluding, IV) }\end{array}$ & $\begin{array}{l}\text { MPO } \downarrow, \text { MDA } \downarrow \text {, and } \\
\text { spinal cord gray } \\
\text { matter motor neurons } \\
\text { injury } \downarrow\end{array}$ & {$[46]$} \\
\hline $\begin{array}{l}\text { Male Wistar albino } \\
\text { rats/intestine }\end{array}$ & $\begin{array}{l}\text { Superior mesenteric artery occlusion } \\
\text { (ischemia } 60 \mathrm{~min} \text {, reperfusion } 60 \mathrm{~min} \text { ) }\end{array}$ & $\begin{array}{l}15 \mathrm{mg} / \mathrm{kg} \\
\text { (both before ischemia and before } \\
\text { reperfusion, IP) }\end{array}$ & $\begin{array}{c}\text { CAT } \uparrow \text {, total } \\
\text { antioxidant capacity } \uparrow \text {, } \\
\text { MPO } \downarrow \text {, total oxidative } \\
\text { status } \downarrow \text {, and oxidative } \\
\text { stress index (OSI) } \downarrow\end{array}$ & {$[105]$} \\
\hline $\begin{array}{l}\text { Male BALB/c } \\
\text { mice/intestine }\end{array}$ & $\begin{array}{l}\text { Superior mesenteric artery occlusion } \\
\quad \text { (ischemia } 1 \mathrm{~h} \text {, reperfusion } 24 \mathrm{~h} \text { ) }\end{array}$ & $\begin{array}{l}50 \mathrm{mg} / \mathrm{kg} \\
\text { (pretreatment } 10 \text { days, } \mathrm{PO})\end{array}$ & $\begin{array}{c}\mathrm{NO} \downarrow \text {, iNOS } \downarrow, \mathrm{MPO} \downarrow \text {, } \\
\text { MDA } \downarrow, \text { SOD } \uparrow \text {, } \\
\text { GSH-Px } \uparrow, \text { SIRT } 1 \uparrow \text {, and } \\
\text { NF-kB } \downarrow\end{array}$ & {$[41]$} \\
\hline $\begin{array}{l}\text { Wistar albino } \\
\text { rats/intestine }\end{array}$ & $\begin{array}{l}\text { Superior mesenteric artery occlusion } \\
\text { (ischemia } 1 \text { hour, reperfusion } 24 \text { h) }\end{array}$ & $\begin{array}{c}15 \mathrm{mg} / \mathrm{kg} \\
\text { (pretreatment } 5 \text { days and } 15 \mathrm{~min} \\
\text { before occlusion, IP) }\end{array}$ & $\begin{array}{l}\mathrm{MPO} \downarrow, \mathrm{MDA} \downarrow, \mathrm{NO} \downarrow \\
\quad \text { and SOD } \uparrow\end{array}$ & {$[43]$} \\
\hline
\end{tabular}


TABLe 1: Continued.

\begin{tabular}{|c|c|c|c|c|}
\hline Species/targets & Model of reperfusion injury & Effective dose & $\begin{array}{l}\text { Effects and } \\
\text { mechanisms }\end{array}$ & References \\
\hline Male Wistar rat/intestine & $\begin{array}{l}\text { Superior mesenteric artery occlusion } \\
\text { (ischemia } 90 \mathrm{~min} \mathrm{~h} \text {, reperfusion } \\
120 \mathrm{~min} \text { ) }\end{array}$ & $\begin{array}{c}0.056 \mathrm{mg} / \mathrm{kg} \\
(30 \mathrm{~min} \text { before occlusion, IV) }\end{array}$ & $\begin{array}{c}\text { Intestine damage } \\
\text { score } \downarrow, \text { MPO } \downarrow \text {, and } \\
\text { hemoglobin content } \downarrow\end{array}$ & {$[42]$} \\
\hline $\begin{array}{l}\text { Male Wistar albino } \\
\text { rats/spleen, ileum }\end{array}$ & $\begin{array}{c}\text { Hepatic artery clamping } \\
\text { (ischemia } 45 \mathrm{~min} \text {, reperfusion } 30 \mathrm{~min} \text { ) }\end{array}$ & $\begin{array}{c}15 \mathrm{mg} / \mathrm{kg} \\
\begin{array}{c}\text { (pretreatment } 5 \text { days and } 15 \mathrm{~min} \\
\text { before occlusion, IP) }\end{array} \\
\end{array}$ & $\begin{array}{c}\mathrm{MDA} \downarrow, \mathrm{NO} \downarrow \text {, and } \\
\mathrm{GSH} \uparrow\end{array}$ & {$[107]$} \\
\hline $\begin{array}{l}\text { Male Wistar albino } \\
\text { rats/kidney }\end{array}$ & $\begin{array}{l}\text { Right nephrectomy and left renal } \\
\text { pedicle clamping } \\
\text { (ischemia } 45 \text { min, reperfusion } 6 \mathrm{~h} \text { ) }\end{array}$ & $\begin{array}{l}30 \mathrm{mg} / \mathrm{kg} \\
(30 \mathrm{~min} \text { prior to ischemia and } \\
\text { immediately before the } \\
\text { reperfusion period, IP) }\end{array}$ & $\begin{array}{c}\mathrm{ROS} \downarrow, \mathrm{MDA} \downarrow, \mathrm{MPO} \downarrow \\
\mathrm{LDH} \downarrow, \mathrm{TNF}-\alpha \downarrow \\
\mathrm{SOD} \uparrow, \text { and GSH} \uparrow\end{array}$ & {$[112]$} \\
\hline Male Wistar rats/kidney & $\begin{array}{l}\text { Renal pedicles clamping } \\
\text { (ischemia } 45 \text { min, reperfusion } 24 \mathrm{~h} \text { ) }\end{array}$ & $\begin{array}{c}5 \mathrm{mg} / \mathrm{kg}, \\
\text { (pretrentment } 30 \text { minutes before } \\
\text { surgery, } \mathrm{PO} \text { ) }\end{array}$ & $\begin{array}{c}\mathrm{NO} \uparrow, \mathrm{BUN} \downarrow \text {, } \\
\text { creatinine } \downarrow \text {, SOD } \uparrow, \\
\mathrm{GSH} \uparrow \text {, and CAT } \uparrow\end{array}$ & {$[117]$} \\
\hline Male Wistar rats/kidney & $\begin{array}{l}\text { Right nephrectomy and left renal } \\
\text { pedicle clamping } \\
\text { (ischemia } 45 \text { min, reperfusion } 24 \mathrm{~h} \text { ) }\end{array}$ & $\begin{array}{c}5 \mathrm{mg} / \mathrm{kg}, \\
\text { (before I/R, PO) }\end{array}$ & $\begin{array}{l}\mathrm{BUN} \downarrow \text {, creatinine } \downarrow \text {, } \\
\mathrm{SOD} \uparrow, \mathrm{GSH} \uparrow, \mathrm{CAT} \uparrow, \\
\text { and NO } \uparrow\end{array}$ & {$[45]$} \\
\hline Male Wistar rats/kidney & $\begin{array}{l}\text { Both renal pedicles cross-clamping } \\
\text { (ischemia } 40 \mathrm{~min} \text {, reperfusion } 24 \mathrm{~h} \text { ) }\end{array}$ & $\begin{array}{c}0.23 \mu \mathrm{g} / \mathrm{kg} \\
(40 \mathrm{~min} \text { before I/R, IV) }\end{array}$ & $\begin{array}{c}\text { Mortality rate } \downarrow \text {, renal } \\
\text { damage } \downarrow \text {, and NO } \uparrow\end{array}$ & {$[113]$} \\
\hline $\begin{array}{l}\text { Male Sprague-Dawley } \\
\text { rat/liver }\end{array}$ & $\begin{array}{c}\text { Clamping the portal vein and hepatic } \\
\text { artery } \\
\text { (ischemia } 1 \mathrm{~h} \text {, reperfusion } 3 \mathrm{~h} \text { ) }\end{array}$ & $\begin{array}{l}0.02 \text { and } 0.2 \mathrm{mg} / \mathrm{kg} \\
\text { (after reperfusion, IV) }\end{array}$ & $\begin{array}{c}\text { IL- } 1 \beta \downarrow, \text { IL- } 6 \downarrow, \text { MPO } \downarrow \text {, } \\
\text { TNF- } \alpha \downarrow, \text { KC } \downarrow \text {, and } \\
\text { HO- } 1 \text { mRNA } \downarrow\end{array}$ & {$[122]$} \\
\hline $\begin{array}{l}\text { Male Sprague-Dawley } \\
\text { rats/liver }\end{array}$ & $\begin{array}{l}\text { Clamping the portal vein and hepatic } \\
\text { artery } \\
\text { (ischemia } 45 \mathrm{~min} \text {, reperfusion } 45 \mathrm{~min} \text { ) }\end{array}$ & $\begin{array}{c}10 \mathrm{mg} / \mathrm{kg} \\
(15 \mathrm{~min} \text { before reperfusion, IV) }\end{array}$ & $\begin{array}{c}\mathrm{MDA} \downarrow, \mathrm{SOD} \uparrow, \mathrm{GSH} \uparrow, \\
\text { and } \mathrm{CAT} \uparrow\end{array}$ & {$[121]$} \\
\hline Sprague-Dawley rat/lung & $\begin{array}{l}\text { Left hilum } \\
\text { (occlusion } 60 \mathrm{~min} \text { ) }\end{array}$ & $\begin{array}{c}20 \mathrm{mg} / \mathrm{kg} \\
(4 \text { days and } 15 \mathrm{~min} \text { before } \\
\text { ischemia, } \mathrm{PO})\end{array}$ & $\begin{array}{c}\text { ROS } \downarrow, \text { MDA } \downarrow \text {, } \\
\text { PGC1- } \alpha \text { mRNA } \uparrow \text {, and } \\
\text { leukocyte infiltration } \downarrow\end{array}$ & {$[126]$} \\
\hline $\begin{array}{l}\text { Male Sprague-Dawley } \\
\text { rat/testis }\end{array}$ & $\begin{array}{l}\text { Left testis torsion/detorsion } \\
\text { (ischemia } 4 \mathrm{~h} \text { ) }\end{array}$ & $\begin{array}{c}20 \mathrm{mg} / \mathrm{kg} \\
(30 \mathrm{~min} \text { before detorsion, } \mathrm{IP}) \\
\end{array}$ & $\begin{array}{c}\text { MDA } \downarrow, \mathrm{H}_{2} \mathrm{O}_{2} \downarrow \text {, and } \\
\text { oxidative stress index } \downarrow\end{array}$ & {$[39]$} \\
\hline Male Wistar rats/testis & $\begin{array}{l}\text { Right testis torsion/detorsion } \\
\text { (ischemia } 4 \mathrm{~h} \text { ) }\end{array}$ & $\begin{array}{c}30 \mathrm{mg} / \mathrm{kg} \\
(30 \mathrm{~min} \text { before detorsion, IP; } 7 \\
\text { days postoperatively, PO) }\end{array}$ & $\begin{array}{c}\text { Improved } \\
\text { contralateral } \\
\text { spermatozoid } \\
\text { production and some } \\
\text { fertility parameters. }\end{array}$ & {$[133]$} \\
\hline Wistar albino rat/ovary & $\begin{array}{c}\text { Right unilateral adnexal } \\
\text { torsion/detorsion } \\
\text { (torsion } 3 \mathrm{~h} \text {, detorsion } 3 \mathrm{~h} \text { ) }\end{array}$ & $\begin{array}{c}10 \mathrm{mg} / \mathrm{kg} \\
(30 \mathrm{~min} \text { before detorsion, IP) }\end{array}$ & $\begin{array}{c}\mathrm{MDA} \downarrow, \mathrm{XO} \downarrow \text {, and } \\
\mathrm{GSH} \uparrow\end{array}$ & {$[140]$} \\
\hline $\begin{array}{l}\text { Male Sprague Dawley } \\
\text { rats/retinal }\end{array}$ & $\begin{array}{l}\text { Anterior chamber saline bag } \\
\text { (intraocular pressure } 70-80 \mathrm{~mm} \mathrm{Hg} \\
\text { for } 45 \mathrm{~min} \text { ) }\end{array}$ & $\begin{array}{c}30 \mathrm{mg} / \mathrm{kg} \\
\text { (pretreatment } 5 \text { days, IP) }\end{array}$ & $\begin{array}{l}\text { Reduce inner retinal } \\
\text { layers thinning }\end{array}$ & {$[145]$} \\
\hline $\begin{array}{l}\text { Male Wistar rats } \\
\text { rat/Retinal }\end{array}$ & $\begin{array}{l}\text { Anterior chamber saline bag } \\
\text { (intraocular pressure } 120 \mathrm{~mm} \mathrm{Hg} \text { for } \\
60 \mathrm{~min} \text { ) }\end{array}$ & $\begin{array}{l}0.5 \text { nmole } \\
\text { (pretreatment } 15 \mathrm{~min}, \mathrm{IV} \text { ) }\end{array}$ & $\begin{array}{c}\text { MMP-9 } \downarrow \text {, iNOS } \downarrow \text {, and } \\
\text { HO- } 1 \uparrow\end{array}$ & [149] \\
\hline $\begin{array}{l}\text { Male Spraque-Dawley } \\
\text { rats/skeletal muscle }\end{array}$ & $\begin{array}{c}\text { Abdominal aorta clamp } \\
\text { (ischemia } 120 \mathrm{~min} \text {, reperfusion } \\
60 \mathrm{~min} \text { ) }\end{array}$ & $\begin{array}{c}20 \mathrm{mg} / \mathrm{kg} \\
\text { (pretreatment for } 14 \text { days, gastric } \\
\text { tube) }\end{array}$ & $\begin{array}{c}\mathrm{MDA} \downarrow, \mathrm{CPK} \downarrow, \mathrm{LDH} \downarrow \\
\mathrm{GSH} \uparrow \text { carbonyl } \downarrow \text {, and } \\
\text { myoglobin } \downarrow \text {, }\end{array}$ & {$[157]$} \\
\hline $\begin{array}{l}\text { Sprague-Dawley } \\
\text { rats/bladder }\end{array}$ & $\begin{array}{c}\text { Abdominal aorta occlusion } \\
\text { (ischemia } 60 \mathrm{~min} \text {, reperfusion } 60 \mathrm{~min} \text { ) }\end{array}$ & $\begin{array}{c}10 \mathrm{mg} / \mathrm{kg} \\
(15 \mathrm{~min} \text { before I/R, IP }) \\
\end{array}$ & $\begin{array}{c}\mathrm{MPO} \downarrow, \mathrm{MDA} \downarrow \\
\mathrm{GSH} \uparrow \\
\end{array}$ & {$[164]$} \\
\hline
\end{tabular}




\section{The Organ-Protective Effects of Resveratrol in Ischemia and Reperfusion Injury}

2.1. Oxidative Stress and Ischemia-Reperfusion Injury. The oxidative stress is still considered to be an important cause of I/R-induced tissue injury. There is a massive increase in oxidants and oxygen radicals during the initiation and progression of I/R injury [50-53]. Ischemia and reperfusion can promote production of ROS, such as superoxide anions $\left(\mathrm{O}_{2}{ }^{-}\right)$, hydroxyl free radicals $\left(\mathrm{HO}^{-}\right)$, hydrogen peroxide $\left(\mathrm{H}_{2} \mathrm{O}_{2}\right)$, and nitric oxide $(\mathrm{NO})$, which is a major factor contributing to I/R-induced organ injury [50, 51, 54, 55]. $\mathrm{I} / \mathrm{R}$-induced reactive oxygen species (ROS) formation is the end result of several different oxidant-producing pathways, such as the mitochondria, xanthine oxidase $(\mathrm{XO})$, and nicotinamide adenine dinucleotide phosphate-oxidase (NOX) [50, $52,56,57]$. Oxygen radicals cause lipid peroxidation that can lead to cell membrane breakdown and mitochondrial damage triggering cell death $[21,58]$. NO plays a protective role in I/R injury as increased NO expression can decrease $\mathrm{I} / \mathrm{R}$-induced organ injury $[59,60]$. In controversy, previous studies have also shown that the inducible NO synthase is upregulated after I/R and can switch from $\mathrm{NO}$ to oxygen radical generation under oxidant stress [41, 61]. Oxidative stress could perturb the balance between oxidant and antioxidant status. In most cells, superoxide dismutase (SOD), catalase (CAT), and glutathione peroxidase (GSH-Px) are endogenous free radical scavenging enzymes induced by oxidative stress [62-64]. These antioxidant enzymes play a critical role in the prevention of oxidative damage during ischemia and reperfusion. In addition, the oxidant formation is generated through a series of interacting pathways in various organs and endothelial cells, triggering subsequent leukocyte chemotaxis and inflammation [20, 50, 65]. However, the pathophysiology of I/R injuries has not yet been fully elucidated due to complex interactions and signaling pathways. Previous evidence shows that resveratrol plays an important role organ protection against $\mathrm{I} / \mathrm{R}$ injury via its antioxidative and anti-inflammatory properties $[20,66,67]$. The protective pathways and mechanisms of resveratrol in ischemia-reperfusion (I/R) will be further discussed in this paper.

2.2. The Cardioprotective Effect of Resveratrol in IschemiaReperfusion Injury. Myocardial ischemia-reperfusion injury is a complex pathophysiological process that involves various factors and pathways [68-71]. An excess amount of ROS is increased during I/R injury that results in myocardiocyte damage. Resveratrol exerts cardiovascular beneficial effects on atherosclerosis, ventricular arrhythmia, and myocardial I/R injury $[4,72,73]$.

Resveratrol could reduce oxidative stress by inhibiting ROS production and has been reported to be a scavenger of hydroxyl, superoxide, metal-induced radicals, and $\mathrm{H}_{2} \mathrm{O}_{2}$ [31, 74-77]. However, the protective effects of resveratrol against oxidative injury are likely to be attributed to the upregulation of the endogenous cellular antioxidant systems rather than its direct ROS scavenging activity. Resveratrol also induces antioxidant enzymes in cardiovascular tissues including SOD, GSH, CAT [72, 74, 78], and NOX [74, 79], all of which are major ROS producing enzymes in the cardiovascular system.

Previous studies have shown that resveratrol-provided cardioprotection is achieved by preserving postischemic ventricular function and reducing myocardial infarct size and cardiomyocytes apoptosis [80]. Pretreatment of rats with resveratrol resulted in cardioprotection in the isolated heart following ischemia and reperfusion $[49,81,82]$ and protected neonatal rat cardiomyocytes against anoxia/reoxygenation injury by antiapoptosis [31]. A recent study has shown that resveratrol improved diabetic cardiomyopathy and postischemic ventricular function through regulating myocardial lipoperoxidation and antioxidant enzyme activities [72, 77, 83]. The protective effect is related with an increased activity of peroxidase and superoxide dismutase and a decreased expression of catalase, malondialdehyde (MDA) and isoprostanes $[80,84]$. However, MDA is not used as a relaible biomarker of oxidative stress. Instead, isoprostane is considered a specific marker of lipid peroxidation for monitoring oxidative stress [85-87].

NO has been identified as a crucial factor mediating the protective effects of resveratrol $[18,88]$. Resveratrol enhances endothelial NO synthase (eNOS) expression in endothelial cells and improves the ventricular function during I/R [18, 88]. SIRT1 has been shown to regulate mammalian genes transcription and has a regulatory function of intracellular signaling in hypoxia or stress $[26,27]$. Recent studies indicated that the upregulation of eNOS expression was mediated by SIRT1 [74, 75, 89]. SIRT1 activation may be necessary for the cardioprotective effect, which is mediated by NO signaling [90]. However, other studies have shown that acutely infused resveratrol had no beneficial effect in intestinal ischemia/reperfusion or stroke and it is not mediated by NO elevation $[41,61]$.

The cardioprotective mechanisms of resveratrol are complex in I/R injury. A previous report demonstrated that there was less myocardial injury and inflammation in Toll-like receptor 4- (TLR4-) deficient mice in I/R. This protective mechanism was possibly associated to the TLR4/nuclear factor-kappa B $(\mathrm{NF}-\kappa \mathrm{B})$ signaling pathway [31, 41]. Furthermore, resveratrol attenuates postischemic leukocyte recruitment and subsequent endothelial dysfunction by superoxiderelated proinflammatory stimulis, such as hypoxanthine (HX)/XO and platelet-activating factor (PAF) [91].

2.3. The Neuroprotective Effect of Resveratrol in IschemiaReperfusion Injury. The mechanisms of brain and spinal cord injuries are complex and multifactorial. Oxidative stress has been regarded as important pathogenesis for neurologic damage after cerebral I/R injury. ROS, like superoxide anions, hydroxyl free radicals, hydrogen peroxide, and nitric oxide, are produced during abnormal metabolic reactions or central nervous system activation in I/R [61, 92]. Previous experimental evidence has demonstrated that resveratrol exhibits neuroprotective effect in various cerebral ischemic stroke animal model $[3,93-95]$. Treatment with transresveratrol 
prevented motor impairment, reduced glutathione levels, and also significantly decreased the infarct size after middle cerebral artery occlusion and reperfusion in rat [96]. The neuroprotective effects of resveratrol were shown to be due to its antioxidative and NO promoting properties $[48,92,97]$. Wang and colleagues also showed that resveratrol decreased cerebral microglial activation and delayed neuronal cell death in gerbils, a beneficial effect attributed to its strong antioxidative activity [48]. Previous studies also showed that resveratrol significantly increased the basal levels of adesonine and inosine, inhibited the elevations of hypoxanthine and xanthine levels, remarkably decreased xanthine oxidase activity, and depressed oxidative biomarker (8-isoprostane) levels [84, 92].

Previous studies suggested that the cerebroprotective action of resveratrol could be mediated by both antioxidative and anti-inflammatory effects [98]. Resveratrol treatment decreased oxidative stress and inflammatory markers like isoprostane, tumor necrosis factor-alpha (TNF- $\alpha$ ), interleukin 6 (IL-6), myeloperoxidase (MPO), and intercellular adhesion molecule 1 (ICAM-1) and increased antioxidative and antiinflammatory markers like superoxide dismutase, catalase, and interleukin 10 (IL-10) levels in brain I/R injury [84, 99]. Resveratrol pretreatment also reduced astroglial and microglial cells activation by attenuating NF- $\kappa \mathrm{B}$ and JNK activation associated with a decrease in inducible nitric oxide synthase (iNOS) and cyclooxygenase-2 (COX-2) production [100]. A recent study has shown that intracortical injection of resveratrol reduced rat cortex infarct volume. This neuroprotective effect was attenuated when resveratrol and a selective estrogen receptor- (ER-) $\alpha$ and ER- $\beta$ antagonist injections were given in combination. These results indicated that neuroprotection of resveratrol is mediated via ER- $\alpha$ and ER- $\beta$ subtypes [23].

In addition, the resveratrol also has protective effect in spinal cord I/R injury. In a rabbit study, prophylactic use of resveratrol decreased malondialdehyde and myeloperoxidase activity and reduced spinal cord gray matter motor neurons damage following abdominal aorta clamping and reperfusion [46]. Kiziltepe et al. [101] also showed that neuroprotective function of resveratrol in spinal cord I/R injury by scavenging free radicals, inhibiting oxidative stress, and upregulating NO.

2.4. The Intestinoprotective Effect of Resveratrol in IschemiaReperfusion Injury. Gastrointestinal tract is highly sensitive to $\mathrm{I} / \mathrm{R}$ injury. Intestinal $\mathrm{I} / \mathrm{R}$ could trigger the release of oxidants and tissue injurious factors, leading to interstitial edema, microvascular permeability change, vasoregulation impairment, mucosal barrier dysfunction, and inflammatory cell infiltration [65, 102-105].

Resveratrol plays a crucial role in intestinal I/R injuries. Previous study demonstrated that resveratrol exerted its broad spectrum of protective mechanisms through increasing its antioxidative capacity and reducing oxidative status and MPO in intestinal $\mathrm{I} / \mathrm{R}$ injury $[20,42,43,105$, 106]. Resveratrol ameliorated the intestinal tissue injury and decreased bacterial translocation in mesenteric lymph nodes via decreased MPO and NO levels and restored SOD activity [43].

Resveratrol at a dose of $0.056 \mathrm{mg} / \mathrm{kg}$ significantly decreased the hemoglobin content, the histopathologic score, and tissue myeloperoxidase activity in intestinal I/R injury, without improving the systemic and metabolic parameters [42]. One study showed that intraperitoneal administration of resveratrol reduced excessive NO formation and diminished rat spleen and ileum oxidative damage after hepatic I/R [107]. Furthermore, resveratrol rendered subacute intestinal protection in vivo. Resveratrol significantly ameliorated subacute intestinal $I / R$ injury $[41,42]$, related to a reduction of $\mathrm{NO}$ production and the activation of the SIRT1-NF- $\kappa$ B pathway, which was associated with a decrease in iNOS expression as well as NO production [41]. NO is an important signaling molecule in antioxidative defense mechanisms and resveratrol relieved tissue $I / R$ injuries through an NO-dependent manner $[15,16,30,108]$. However, its protective or detrimental effect in intestinal $\mathrm{I} / \mathrm{R}$ injury is still controversial. Some studies showed that an augmented NO production can protect the intestine following I/R injury $[12,109]$. Other evidence indicated that a decreased production of NO may have a protective role via with the suppression of inducible NOS in the small intestine I/R $[41,98,110]$.

\subsection{The Renoprotective Effect of Resveratrol in Ischemia-Reper-} fusion Injury. Renal I/R causes an increase in ROS and isoprostane levels and a decrease of the antioxidant enzyme glutathione in the urological system [111]. Resveratrol may induce the GSH synthesis enzymes and maintain the GSH levels during oxidative stress $[45,112,113]$. It has been shown that resveratrol could maintain antioxidant defenses and reduce the oxidative damage of kidney $[45,113]$. Pretreatment with resveratrol prevented the renal I/R-induced lipid peroxidation and protected the depletion of antioxidant enzyme in the renal I/R-treated rats. Moreover, oxidative injury of the kidneys was accompanied by neutrophil infiltration, as evidenced by the elevated tissue MPO levels. In addition, oxidative stress could be involved in renal glomerular lesions caused by a series of proinflammatory mediators, including cytokines and chemokines that lead to the ROS production, leukocyte activation, and glomerular damage [112]. ROS play an important role in the pathologic process of renal ischemia reperfusion injury. Previous study showed that the shortterm treatment of resveratrol inhibited renal lipid peroxidation induced by IR. Resveratrol administration decreased renal cortex and medulla damage and reduced the mortality of ischemic rats from $50 \%$ to $10 \%$ [113].

NO expression is generated in renal tissue and plays an important role in the regulation of renal blood flow and glomerular filtration function. In kidney, resveratrol was found to exert its protective action through the upregulation of NO. Previous studies demonstrated that resveratrol could stimulate NO production during renal I/R [45, 113-116]. Preconditioning and resveratrol treatment also led to a marked increase in NO levels in kidneys and protect renal cells from I/R injury [117]. The protective phenomenon of resveratrol 
was suggested to be through the NO-dependent mechanism [113]. Another report also evidenced that treatment with LNAME (an NO synthase inhibitor) attenuated this protection afforded by resveratrol, indicating that resveratrol exerted its protective effect through the release of NO [45].

\subsection{The Hepatoprotective Effect of Resveratrol in Ischemia-} Reperfusion Injury. I/R stimulates the hepatic Kupffer cells and the residing macrophage activation, to generate ROS and proinflammatory cytokines and to upregulate iNOS $[60,118]$. The activation of Kupffer cell (KC) with enhanced ROS production and secretion of inflammatory cytokines and proteolytic enzymes is considered to play an important role in liver reperfusion injury $[40,119]$. Additionally, the activation of polymorphonuclear leukocytes migration and infiltration in the injury site may enhance the production of inflammatory cytokines, adhesion molecules, and ROS $[40,120]$.

Previous studies showed that resveratrol reduced liver damage after ischemia-reperfusion. This beneficial effect was due to the replacement of the depleted antioxidant defense system in hepatic I/R injury [121, 122]. Transresveratrol has also been suggested to decrease the superoxide and improve NO bioavailability. Postischemic treatment with lower dose transresveratrol $(0.02 \mathrm{mg} / \mathrm{kg})$ reduced $\mathrm{TNF}-\alpha$, interleukin $1 \beta$ (IL-1 $\beta$ ), keratinocyte chemoattractant (KC), and HO-1 hepatic mRNA expression and decreased hepatic neutrophil recruitment [122]. Gedik et al. [121] reported that resveratrol treatment decreased the lipid peroxidation and protected the depletion of antioxidant enzymes (SOD, CAT, and GSH) in rat model of common hepatic artery and portal vein clamping and reperfusion-induced hepatic injury.

2.7. The Pulmonoprotective Effect of Resveratrol in IschemiaReperfusion Injury. Lung I/R injury occurs in lung transplantation and cardiopulmonary surgery, resulting in an excessive production of reactive ROS [37, 123-125]. The exact mechanism in I/R-induced lung injury is not completely understood. However, an overproduction of ROS such as superoxide and peroxides, activation of macrophages, and infiltration of polymorphonuclear leukocytes are implicated in pulmonary injury [125]. Previous study [89] demonstrated that I/R-induced lung tissue damage was related to pulmonary mitochondrial dysfunction. Peroxisome proliferatoractivated receptor-gamma coactivator 1 alpha (PGC- $1 \alpha$ ) was a coactivator controlling aerobic capacity and mitochondrial biogenesis, and an increase in PGC- $1 \alpha$ mRNA expression was associated with a decreased pulmonary oxidative stress and improved aerobic capacity. Recent study [126] demonstrated that PGC- $1 \alpha$ mRNA expression in the lungs was markedly improved with resveratrol, providing protection against pulmonary damage induced by contralateral lung I/R injury. Resveratrol treatment also effectively reduced the lipid peroxidation and alveolar neutrophils and maintained mitochondrial homeostasis. In addition, resveratrol could increase mitochondrial activity through upregulating PGC$1 \alpha$ and SIRT1 expression [89].
2.8. The Reproductive Organs Protective Effect of Resveratrol in Ischemia-Reperfusion Injury. Testicular torsion is urological emergency in which damaged germinal cells may lead to infertility [127-129]. Testicular torsion and detorsion may be regarded as an ischemia/reperfusion (I/R) injury. Oxidative stress is thought to be a major responsible in $I / R$ injury; however, the mechanism involved in testicular injury has not been fully understood. Previous reports demonstrated that ipsilateral testicular torsion could affect the contralateral testis. The injuries caused by $\mathrm{I} / \mathrm{R}$ were observed in the ipsilateral and contralateral testis $[130,131]$. Resveratrol could decrease the cell injury by preventing lipid peroxidation in the cell membrane and DNA damage caused by excessive ROS production [39, 47, 132]. Previous study indicated that treatment with resveratrol improved fertility parameters and contralateral spermatozoid production [133]. A recent report showed that resveratrol pretreatment decreased tissue lipid peroxidation and had a protective effect in the prevention of apoptosis in rat testicular torsion/detorsion (T/D) model [39].

Ovarian torsion is also a gynecological emergency due to the twisting of the adnexa on its ligamentous support. Insufficiency in tissue blood flow due to various reasons such as torsion or embolism leads to ischemia [134, 135]. The levels of ROS and MDA are increased during the reperfusion period following ischemia. It is known that xanthine oxidase is an important source of the ROS production [136, 137] during I/R and GSH is an essential component of the cellular defense mechanism against oxidative cell damage [138, 139]. Hascalik et al. [140] reported that intraperitoneal resveratrol $(10 \mathrm{mg} / \mathrm{kg})$ administration reduced the tissue XO products, as well as restored GSH levels, and decreased rat ovarian damage following T/D injury.

\subsection{The Ophthalmoprotective Effect of Resveratrol in Ischemia-} Reperfusion Injury. The retina is a very sensitive neural structure that is easily damaged by free radicals and inflammation following ischemia-reperfusion injury $[141,142]$. Retinal ischemia is a common cause of visual loss and impairment. I/R-induced neural injuries are associated with enhanced production of endogenous oxidants such as oxygen free radicals, NO, and calcium [141, 143, 144]. Previous studies showed that resveratrol was capable of crossing the bloodretina barrier and exerting its neuroprotective effects, including cerebral and retinal IR injuries. Vin et al. [145] reported that resveratrol prophylactic treatment attenuated ischemicinduced loss of retinal function and reduced ischemiamediated thinning of inner retinal layers [145]. Li et al. also showed that pretreatment of resveratrol decreased retinal vascular degeneration by inhibiting endoplasmic reticulum stress in retinal ischemic injury; however, it did not prevent retinal neuronal cell loss [146].

Previous studies showed that matrix metallopeptidase 9 (MMP-9) expression was upregulated during brain ischemia [147] and HO-1 overexpression attenuated retinal cellular damage by intense light exposure [148]. In addition, resveratrol exerted retinal protective effects via modulation of NOS in oxygen-induced retinopathy. Recent study also evidenced 
that the administration of resveratrol might protect the retina against ischemia by inhibiting iNOS and MMP-9 expression and upregulating HO-1 levels [149].

2.10. The Musculoprotective Effect of Resveratrol in IschemiaReperfusion Injury. I/R injuries of skeletal muscles are serious clinical problems and are commonly seen in a variety of injuries including traumatic damage, peripheral vascular surgery, plastic surgery, or limb surgery with long time tourniquet application [150-152]. I/R injury of skeletal muscle can increase free radicals production and activate ROS generation, with the ability to produce cell membrane damage and leukocyte infiltration [153-155]. Resveratrol is an effective scavenger of hydroxyl and superoxide and exhibits a protective effect to decrease cell membranes lipid peroxidation and free radicals induced DNA damage $[153,154,156]$. Previous studies have shown that dietary flavonoid resveratrol can protect the skeletal muscle tissue against ischemia and reperfusion injury because of its strong antioxidant properties [157]. Elmali et al. indicated that intraperitoneal resveratrol treatment could exert a protective effect against tourniquetinduced I/R injury in rat gastrocnemius muscle. However, resveratrol not only functioned as an antioxidant but also attenuated the neutrophil infiltration in damaged skeletal muscle [158].

2.11. The Vesicoprotective Effect of Resveratrol in IschemiaReperfusion Injury. Urinary bladder I/R injury is associated with vascular atherosclerotic disease or pelvic embolization operations $[159,160]$. Bladder ischemia could result in detrusor contractility impairment and bladder dysfunction [161, $162]$. Previous study showed that I/R injury induced a production of isoprostanes $[85,86]$ and a decrease in endogenous GSH, as well as an enhanced neutrophil infiltration in rat bladder [162, 163]. However, resveratrol treatment reduced bladder inflammatory cell infiltration, lipid peroxidation, and the myeloperoxidase activity in I/R injury. Resveratrol treatment also reversed the bladder contractile responses to carbachol and prevented oxidative tissue damage following I/R [164].

\section{The Organ-Protective Effect of Resveratrol in Hemorrhage and Reperfusion Injury}

Reperfusion injury after hemorrhage results in an excessive production of oxidants and proinflammatory mediators. The enhanced ROS and proinflammatory cytokines play important factors in the initiation and perpetuation of organ injury $[67,165]$. Previous studies have shown that vascular endothelial cell dysfunction can lead to inadequate tissue perfusion, which occurs after hemorrhagic shock and persists despite fluid resuscitation $[166,167]$. Oxidative stress and superoxide radical generation are believed to contribute to the pathogenesis of endothelial dysfunction in low-flow states $[167,168]$. Endothelial NOX is a major source of ROS of the vasculature, and previous studies have shown that there is a marked increase in NOX-generated ROS by the endothelium under stressful conditions $[169,170]$. Elevated
ROS is considered a major contributing factor to endothelial dysfunction, and antioxidants have been found to attenuate ROS-induced injuries $[168,169]$. Resveratrol has been shown to have broad antioxidative activities in a number of biological systems [170]. Our previous studies have shown that resveratrol prevented hemorrhagic shock-elicited oxidative stress and protected endothelium from subsequent functional damages [168]. The beneficial effects included the suppression of the NOX activity and direct scavenging of ROS. The inhibitory effect of resveratrol on the NOX activity appeared to be mediated through influence of the active NOX enzyme complex assembly in the cell membrane and the cytosol, as evidenced from reduced membrane-bound proteins $\mathrm{p} 22 \mathrm{phox}$ and gp91phox and cytosolic protein p47phox [166, 168].

The SIRT1 transcription-modulating proteins showed a fine balance in response to intracellular cues such as hypoxia or stress signals. The beneficial effects of resveratrol mediated by SIRT1 activation can be contributed to by different organs $[26,171,172]$. Studies showed that resveratrol decreased oxidative stress-induce ROS elevation and reduced brain neuron injury by radiation through the activation of SIRT1 [171].

HO-1 appears to act as a protective agent in many organs against insults, such as ischemia and oxidative stress [173, 174]. Previous studies have shown that resveratrol binds and increases the transcriptional activity of ER- $\alpha$ and ER$\beta$. Resveratrol can modulate $\mathrm{HO}-1$ induction and previous studies have shown that estrogen or flutamide enhances HO-1 expression via ER [174-176]. Our previous studies suggested that the upregulation in $\mathrm{HO}-1$ was associated with the prevention of endothelial dysfunction and the salutary effects of resveratrol on endothelial function, mediated in part by an upregulation of the HO-1-related pathway via ER [165]. The p38 MAPK and Akt have been reported to regulate inflammatory response after trauma hemorrhage $[20,174]$. PI3K/Akt pathway is known to play a pivotal role in the ability of neutrophils to undergo chemotaxis. Blockade of Akt activation abolishes the salutary effects of resveratrol in the heart following reperfusion injury [177, 178]. Estrogen-mediated attenuation of the inflammatory response to shock-induced organ injury is abolished by the presence of a p38 MAPK inhibitor (SB-203580) [20, 174]. Previous study also showed that resveratrol administration after hemorrhagic shock upregulated p38 MAPK and Akt expression via HO-1-related pathway $[20,179]$. Neutrophils are activated following hemorrhage/reperfusion injury and activated neutrophils appear to infiltrate the injured organs in parallel with increased expression of adhesion molecules on endothelial cells. Upregulation of $\mathrm{HO}-1$ causes a reduction of cytokines, adhesion molecules, chemokines, and neutrophil accumulation and ameliorates organ injury in shock status $[20,180]$.

\section{Conclusions}

Resveratrol has been indicated to have many beneficial effects in various studies and experimental conditions. There is increasing evidence suggesting that resveratrol protects 


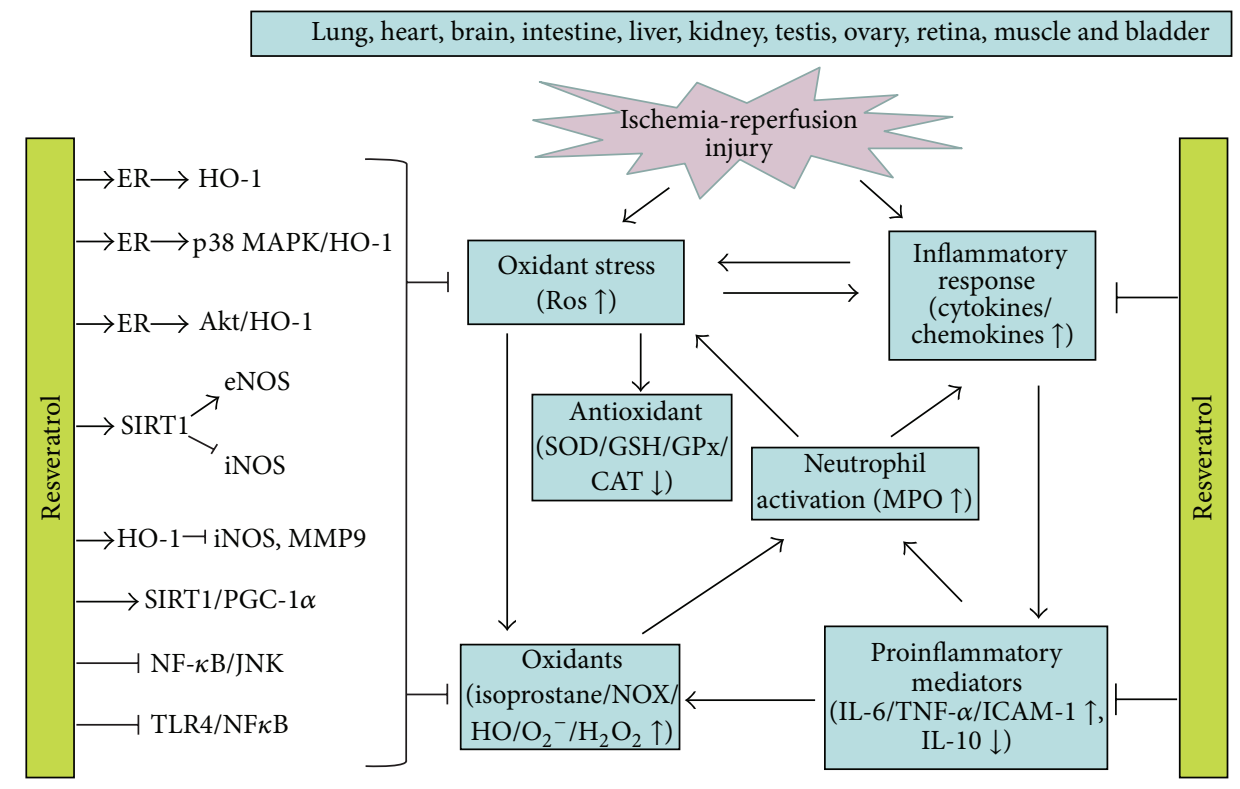

FIGURE 1: The mechanisms and pathways of resveratrol in oxidative stress-mediated ischemia-reperfusion injury. The protective benefits of resveratrol involved are its scavenging, antioxidant, and anti-inflammatory effect and the signaling mechanisms mediated may be via a variety of intracellular signaling pathways, including upregulation of ER-related MAPK/HO-1 and Sirt1/PGC-1 $\alpha$ pathway and inhibition of the TLR4 and NF- $\kappa$ B dependent pathway. ROS, reactive oxygen species; ER, estrogen receptor; HO-1, hemeoxygenase 1; SIRT1, sirtuin 1; eNOS, endothelial nitric oxide synthase; iNOS, inducible nitric oxide synthase; TLR4, Toll-like receptor 4; PGC-1 $\alpha$, peroxisome proliferatoractivated receptor-gamma coactivator 1 alpha; NF- $\kappa$ B, nuclear factor-kappa B; JNK, c-Jun N-terminal kinase; p38 MAPK, p38 mitogenactivated protein kinase; MMP-9, metallopeptidase 9; SOD, superoxide dismutase; CAT, catalase; GSH, glutathione; GSH-Px, glutathione peroxidase (GSH-Px); NOX, NADPH oxidase; XO, xanthine oxidase; $\mathrm{O}_{2}{ }^{-}$, superoxide anions; $\mathrm{HO}^{-}$, hydroxyl free radicals; $\mathrm{H}_{2} \mathrm{O}_{2}$, hydrogen peroxide; TNF- $\alpha$, tumor necrosis factor-alpha; IL-6, interleukin 6; IL-10, interleukin 10; ICAM-1, intercellular adhesion molecule 1; MPO, myeloperoxidase.

organ function after ischemia or shock-like reperfusion injury. Resveratrol can attenuate organs reperfusion injury through multiple pathways. However, the protective benefits of resveratrol may not simply be attributed by its scavenging, antioxidative, or anti-inflammatory effect. It is implicated that resveratrol is also mediated in part via a variety of intracellular signaling pathways including the regulation of the NOS, HO- 1 , SIRT1, ER, MAPK, PGC- $1 \alpha$, TLR4, and $\mathrm{NF}-\kappa \mathrm{B}$ (Figure 1). This complex network needs additional elucidation, more experimental studies, and clinical trials. Resveratrol might be a preventive and therapeutic agent to protect reperfusion-induced organ injury in future clinical treatment.

\section{Abbreviations}

I/R: Ischemia-reperfusion

IP: Intraperitonium

IV: Intravenous

PO: Orally

MAP: Mean arterial pressure

ROS: Reactive oxygen species

ER: Estrogen receptor

HO-1: Hemeoxygenase-1

PGC-1 $\alpha$ : Peroxisome proliferator-activated receptor-gamma coactivator 1 alpha
NF- $\kappa$ B: Nuclear factor-kappa B

JNK: c-Jun N-terminal kinase

MMP-9: Metallopeptidase 9

SOD: $\quad$ Superoxide dismutase

CAT: Catalase; GSH: glutathione

NOX: Nicotinamide adenine dinucleotide phosphate-oxidase

$\mathrm{XO}$ : Xanthine oxidase

$\mathrm{H}_{2} \mathrm{O}_{2}$ : hydrogen peroxide

TNF- $\alpha$ : tumor necrosis factor-alpha

IL-6: $\quad$ Interleukin 6

IL-10: Interleukin 10

ICAM-1: Intercellular adhesion molecule 1

MPO: Myeloperoxidase

NO: $\quad$ Nitric oxide

iNOS: inducible nitric oxide synthase.

\section{Conflict of Interests}

The authors declare that they have no competing interests.

\section{Authors' Contribution}

Huang-Ping $\mathrm{Yu}, \mathrm{MD}, \mathrm{PhD}$, is the principle investigator for the studies providing oversight and contributed fundamental conceptualization for the research, writing a grant proposal 
and paper. Fu-Chao Liu, MD, $\mathrm{PhD}$ contributed to paper preparation and data collection and assisted in writing the paper. Hsin-I Tsai, MD, assisted in writing the paper.

\section{Acknowledgments}

This work was partially supported by grants from the National Science Council (NSC102-2314-B-182A-051-MY3) and Chang Gung Memorial Hospital (CMRPG3B1052 and CMRPG3B1053) to Huang-Ping Yu. Support was also provided by the National Science Council (NSC103-2314B-182-046-MY2) and Chang Gung Memorial Hospital (CMRPG3B1622) to Fu-Chao Liu.

\section{References}

[1] J. A. Santos, G. S. G. de Carvaho, V. Oliveira, N. R. B. Raposo, and A. D. Da Silva, "Resveratrol and analogues: a review of antioxidant activity and applications to human health," Recent Patents on Food, Nutrition \& Agriculture, vol. 5, no. 2, pp. 144153, 2013.

[2] R. F. Guerrero, M. C. Garcia-Parrilla, B. Puertas, and E. CantosVillar, "Wine, resveratrol and health: a review," Natural Product Communications, vol. 4, no. 5, pp. 635-658, 2009.

[3] J. Ren, C. Fan, N. Chen, J. Huang, and Q. Yang, "Resveratrol pretreatment attenuates cerebral ischemic injury by upregulating expression of transcription factor Nrf2 and HO-1 in Rats," Neurochemical Research, vol. 36, no. 12, pp. 2352-2362, 2011.

[4] P. K. Gupta, D. J. DiPette, and S. C. Supowit, "Protective effect of resveratrol against pressure overload-induced heart failure," Food Science \& Nutrition, vol. 2, no. 3, pp. 218-229, 2014.

[5] L. Liu, H. Gu, H. Liu et al., "Protective effect of resveratrol against IL-1 $\beta$-induced inflammatory response on human osteoarthritic chondrocytes partly via the TLR4/MyD88/NF- $\kappa \mathrm{B}$ signaling pathway: an "in vitro study'"' International Journal of Molecular Sciences, vol. 15, no. 4, pp. 6925-6940, 2014.

[6] M. Kitada and D. Koya, "Renal protective effects of resveratrol," Oxidative Medicine and Cellular Longevity, vol. 2013, Article ID 568093, 8 pages, 2013.

[7] J. Tome-Carneiro, M. Gonzalvez, M. Larrosa et al., "Resveratrol in primary and secondary prevention of cardiovascular disease: a dietary and clinical perspective," Annals of the New York Academy of Sciences, vol. 1290, no. 1, pp. 37-51, 2013.

[8] K. Legg, "Metabolic disease: identifying novel targets of resveratrol," Nature Reviews Drug Discovery, vol. 11, no. 4, article 273, 2012.

[9] K. Magyar, R. Halmosi, A. Palfi et al., "Cardioprotection by resveratrol: a human clinical trial in patients with stable coronary artery disease," Clinical Hemorheology and Microcirculation, vol. 50, no. 3, pp. 179-187, 2012.

[10] F. Li, Q. Gong, H. Dong, and J. Shi, "Resveratrol, a neuroprotective supplement for Alzheimer's disease," Current Pharmaceutical Design, vol. 18, no. 1, pp. 27-33, 2012.

[11] L. M. Chu, A. D. Lassaletta, M. P. Robich, and F. W. Sellke, "Resveratrol in the prevention and treatment of coronary artery disease," Current Atherosclerosis Reports, vol. 13, no. 6, pp. 439446, 2011.

[12] L. G. Wood, P. A. B. Wark, and M. L. Garg, "Antioxidant and anti-inflammatory effects of resveratrol in airway disease," Antioxidants \& Redox Signaling, vol. 13, no. 10, pp. 1535-1548, 2010.
[13] L. Di Renzo, A. Carraro, R. Valente, L. Iacopino, C. Colica, and A. De Lorenzo, "Intake of red wine in different meals modulates oxidized LDL level, oxidative and inflammatory gene expression in healthy people: a randomized crossover trial," Oxidative Medicine and Cellular Longevity, vol. 2014, Article ID 681318, 9 pages, 2014.

[14] W. Yu, Y.-C. Fu, and W. Wang, "Cellular and molecular effects of resveratrol in health and disease," Journal of Cellular Biochemistry, vol. 113, no. 3, pp. 752-759, 2012.

[15] A. Csiszar, "Anti-inflammatory effects of resveratrol: possible role in prevention of age-related cardiovascular disease," Annals of the New York Academy of Sciences, vol. 1215, no. 1, pp. 117-122, 2011.

[16] A. A. E. Bertelli, M. Migliori, V. Panichi et al., "Resveratrol, a component of wine and grapes, in the prevention of kidney disease," Annals of the New York Academy of Sciences, vol. 957, pp. 230-238, 2002.

[17] A. Gulcubuk, D. Haktanir, A. Cakiris et al., "The effects of resveratrol on tissue injury, oxidative damage, and proinflammatory cytokines in an experimental model of acute pancreatitis," Journal of Physiology and Biochemistry, vol. 70, no. 2, pp. 397-406, 2014.

[18] S. Wang, Y. Qian, D. Gong, Y. Zhang, and Y. Fan, "Resveratrol attenuates acute hypoxic injury in cardiomyocytes: correlation with inhibition of iNOS-NO signaling pathway," European Journal of Pharmaceutical Sciences, vol. 44, no. 3, pp. 416-421, 2011.

[19] B. Budak, M. Seren, N. N. Turan, Z. Sakaogullari, and A. T. Ulus, "The protective effects of resveratrol and L-NAME on visceral organs following aortic clamping," Annals of Vascular Surgery, vol. 23, no. 5, pp. 675-685, 2009.

[20] H.-P. Yu, T.-L. Hwang, P.-W. Hsieh, and Y.-T. Lau, "Role of estrogen receptor-dependent upregulation of P38 MAPK/heme oxygenase 1 in resveratrol-mediated attenuation of intestinal injury after trauma-hemorrhage," Shock, vol. 35, no. 5, pp. 517523, 2011.

[21] P. Antonuccio, L. Minutoli, C. Romeo et al., "Lipid peroxidation activates mitogen-activated protein kinases in testicular ischemia-reperfusion injury," The Journal of Urology, vol. 176, no. 4, part 1, pp. 1666-1672, 2006.

[22] J. C. Nwachukwu, S. Srinivasan, N. E. Bruno et al., "Resveratrol modulates the inflammatory response via an estrogen receptorsignal integration network," eLife, vol. 3, Article ID e02057, 2014.

[23] M. C. Saleh, B. J. Connell, and T. M. Saleh, "Resveratrol induced neuroprotection is mediated via both estrogen receptor subtypes, ER $\alpha$ and ER $\beta$," Neuroscience Letters, vol. 548, pp. 217221, 2013.

[24] H.-P. Yu, J.-C. Hsu, T.-L. Hwang, C.-H. Yen, and Y.-T. Lau, "Resveratrol attenuates hepatic injury after trauma-hemorrhage via estrogen receptor-related pathway," Shock, vol. 30, no. 3, pp. 324-328, 2008.

[25] W. Xu, Y. Lu, J. Yao et al., "Novel role of resveratrol: suppression of HMGB1 nucleocytoplasmic translocation by the upregulation of SIRT1 in sepsis-induced liver injury," Shock, 2014.

[26] B. Jian, S. Yang, I. H. Chaudry, and R. Raju, "Resveratrol restores sirtuin 1 (SIRT1) activity and pyruvate dehydrogenase kinase 1 (PDK1) expression after hemorrhagic injury in a rat model," Molecular Medicine, vol. 20, no. 1, pp. 10-16, 2014.

[27] T. Li, J. Zhang, J. Feng et al., "Resveratrol reduces acute lung injury in a LPS-induced sepsis mouse model via activation of Sirtl," Molecular Medicine Reports, vol. 7, no. 6, pp. 1889-1895, 2013. 
[28] Y. Fu, Y. Wang, L. Du et al., "Resveratrol inhibits ionising irradiation-induced inflammation in MSCs by activating Sirtl and limiting NLRP-3 inflammasome activation," International Journal of Molecular Sciences, vol. 14, no. 7, pp. 14105-14118, 2013.

[29] V. Kesherwani, F. Atif, S. Yousuf, and S. K. Agrawal, "Resveratrol protects spinal cord dorsal column from hypoxic injury by activating Nrf-2," Neuroscience, vol. 241, pp. 80-88, 2013.

[30] J. Zhang, J. Chen, J. Yang et al., "Resveratrol attenuates oxidative stress induced by balloon injury in the rat carotid artery through actions on the ERK1/2 and NF-kappa B pathway," Cellular Physiology and Biochemistry, vol. 31, no. 2-3, pp. 230-241, 2013.

[31] C. Zhang, G. Lin, W. Wan et al., "Resveratrol, a polyphenol phytoalexin, protects cardiomyocytes against anoxia/reoxygenation injury via the TLR4/NF- $\kappa$ B signaling pathway," International Journal of Molecular Medicine, vol. 29, no. 4, pp. 557563, 2012.

[32] N. Atmaca, H. T. Atmaca, A. Kanici, and T. Anteplioglu, "Protective effect of resveratrol on sodium fluoride-induced oxidative stress, hepatotoxicity and neurotoxicity in rats," Food and Chemical Toxicology, vol. 70, pp. 191-197, 2014.

[33] W. Zhang, C. Guo, R. Gao, M. Ge, Y. Zhu, and Z. Zhang, “The protective role of resveratrol against arsenic trioxide-induced cardiotoxicity," Evidence-Based Complementary and Alternative Medicine, vol. 2013, Article ID 407839, 8 pages, 2013.

[34] H. X. Zhang, G. L. Duan, C. N. Wang et al., "Protective effect of resveratrol against endotoxemia-induced lung injury involves the reduction of oxidative/ nitrative stress," Pulmonary Pharmacology and Therapeutics, vol. 27, no. 2, pp. 150-155, 2014.

[35] G. Şimşek, Ş. Gürocak, N. Karadag et al., "Protective effects of resveratrol on salivary gland damage induced by total body irradiation in rats," Laryngoscope, vol. 122, no. 12, pp. 2743-2748, 2012.

[36] Y.-F. Liao, W. Zhu, D.-P. Li, and X. Zhu, "Heme oxygenase-1 and gut ischemia/reperfusion injury: a short review," World Journal of Gastroenterology, vol. 19, no. 23, pp. 3555-3561, 2013.

[37] P. D. Weyker, C. A. J. Webb, D. Kiamanesh, and B. C. Flynn, "Lung ischemia reperfusion injury: a bench-to-bedside review," Seminars in Cardiothoracic and Vascular Anesthesia, vol. 17, no. 1, pp. 28-43, 2013.

[38] A. J. Vardanian, R. W. Busuttil, and J. W. Kupiec-Weglinski, "Molecular mediators of liver ischemia and reperfusion injury: a brief review," Molecular Medicine, vol. 14, no. 5-6, pp. 337-345, 2008.

[39] E. Yulug, S. Türedi, E. Karagüzel, O. Kutlu, A. MenteSe, and A. Alver, "The short term effects of resveratrol on ischemiareperfusion injury in rat testis," Journal of Pediatric Surgery, vol. 49, no. 3, pp. 484-489, 2014.

[40] R. D. Powell, J. H. Swet, K. L. Kennedy, T. T. Huynh, I. H. McKillop, and S. L. Evans, "Resveratrol attenuates hypoxic injury in a primary hepatocyte model of hemorrhagic shock and resuscitation," Journal of Trauma and Acute Care Surgery, vol. 76, no. 2, pp. 409-417, 2014.

[41] W. Dong, F. Li, Z. Pan et al., "Resveratrol ameliorates subacute intestinal ischemia-reperfusion injury," Journal of Surgical Research, vol. 185, no. 1, pp. 182-189, 2013.

[42] F. Petrat and H. De Groot, "Protection against severe intestinal ischemia/reperfusion injury in rats by intravenous resveratrol," Journal of Surgical Research, vol. 167, no. 2, pp. e145-e155, 2011.

[43] O. V. Ozkan, M. F. Yuzbasioglu, H. Ciralik et al., "Resveratrol, a natural antioxidant attenuates intestinal ischemia/reperfusion injury in rats," The bTohoku Journal of Experimental Medicine, vol. 218, no. 3, pp. 251-258, 2009.
[44] W. Dong, X. Zhang, D. Gao, and N. Li, "Cerebral angiogenesis induced by resveratrol contributes to relieve cerebral ischemicreperfusion injury," Medical Hypotheses, vol. 69, no. 1, pp. 226227, 2007.

[45] V. Chander and K. Chopra, "Protective effect of nitric oxide pathway in resveratrol renal ischemia-reperfusion injury in rats," Archives of Medical Research, vol. 37, no. 1, pp. 19-26, 2006.

[46] S. Kaplan, G. Bisleri, J. A. Morgan, F. H. Cheema, and M. C. Oz, "Resveratrol, a natural red wine polyphenol, reduces ischemiareperfusion- induced spinal cord injury," Annals of Thoracic Surgery, vol. 80, no. 6, pp. 2242-2249, 2005.

[47] S. Uguralp, B. Mizrak, and A. B. Karabulut, "Resveratrol reduces ischemia reperfusion injury after experimental testicular torsion," European Journal of Pediatric Surgery, vol. 15, no. 2, pp. 114-119, 2005.

[48] Q. Wang, J. Xu, G. E. Rottinghaus et al., "Resveratrol protects against global cerebral ischemic injury in gerbils," Brain Research, vol. 958, no. 2, pp. 439-447, 2002.

[49] P. S. Ray, G. Maulik, G. A. Cordis, A. A. E. Bertelli, and D. K. Das, "The red wine antioxidant resveratrol protects isolated rat hearts from ischemia reperfusion injury," Free Radical Biology \& Medicine, vol. 27, no. 1-2, pp. 160-169, 1999.

[50] Z. Xia, Y. Chen, Q. Fan, and M. Xue, "Oxidative stressmediated reperfusion injury: mechanism and therapies," Oxidative Medicine and Cellular Longevity, vol. 2014, Article ID 373081, 2 pages, 2014.

[51] D. K. de Vries, K. A. Kortekaas, D. Tsikas et al., "Oxidative damage in clinical ischemia/reperfusion injury: a reappraisal," Antioxidants \& Redox Signaling, vol. 19, no. 6, pp. 535-545, 2013.

[52] P. W. Kleikers, K. Wingler, J. J. Hermans et al., "NADPH oxidases as a source of oxidative stress and molecular target in ischemia/reperfusion injury," Journal of Molecular Medicine, vol. 90, no. 12, pp. 1391-1406, 2012.

[53] L. Ji, F. Fu, L. Zhang et al., "Insulin attenuates myocardial ischemia/reperfusion injury via reducing oxidative/nitrative stress," The American Journal of Physiology-Endocrinology and Metabolism, vol. 298, no. 4, pp. E871-E880, 2010.

[54] G. H. Heeba and A. A. El-Hanafy, "Nebivolol regulates eNOS and iNOS expressions and alleviates oxidative stress in cerebral ischemia/reperfusion injury in rats," Life Sciences, vol. 90, no. 11-12, pp. 388-395, 2012.

[55] S. C. Weight and M. L. Nicholson, "Nitric oxide and renal reperfusion injury: a review," European Journal of Vascular and Endovascular Surgery, vol. 16, no. 2, pp. 98-103, 1998.

[56] Y. Yang, W. Duan, Y. Lin et al., "SIRT1 activation by curcumin pretreatment attenuates mitochondrial oxidative damage induced by myocardial ischemia reperfusion injury," Free Radical Biology \& Medicine, vol. 65, pp. 667-679, 2013.

[57] H. Okabe, "The role of xanthine dehydrogenase (xanthine oxidase) in ischemia-reperfusion injury in rat kidney," Japanese Journal of Nephrology, vol. 38, no. 12, pp. 577-584, 1996.

[58] F. Yaylak, H. Canbaz, M. Caglikulekci et al., "Liver tissue inducible nitric oxide synthase ( iNOS ) expression and lipid peroxidation in experimental hepatic ischemia reperfusion injury stimulated with lipopolysaccharide: the role of aminoguanidine," Journal of Surgical Research, vol. 148, no. 2, pp. 214-223, 2008.

[59] A. Folino, G. Losano, and R. Rastaldo, "Balance of nitric oxide and reactive oxygen species in myocardial reperfusion injury and protection," Journal of Cardiovascular Pharmacology, vol. 62, no. 6, pp. 567-575, 2013. 
[60] M. Abu-Amara, S. Y. Yang, A. Seifalian, B. Davidson, and B. Fuller, "The nitric oxide pathway-evidence and mechanisms for protection against liver ischaemia reperfusion injury," Liver International, vol. 32, no. 4, pp. 531-543, 2012.

[61] F. Simão, A. Matté, C. Matté et al., "Resveratrol prevents oxidative stress and inhibition of $\mathrm{Na}^{+} \mathrm{K}^{+}$-ATPase activity induced by transient global cerebral ischemia in rats," The Journal of Nutritional Biochemistry, vol. 22, no. 10, pp. 921-928, 2011.

[62] A. M. Arent, L. F. D. Souza, R. Walz, and A. L. Dafre, "Perspectives on molecular biomarkers of oxidative stress and antioxidant strategies in traumatic brain injury," BioMed Research International, vol. 2014, Article ID 723060, 18 pages, 2014.

[63] P. O. Eghwrudjakpor and A. B. Allison, "Oxidative stress following traumatic brain injury: enhancement of endogenous antioxidant defense systems and the promise of improved outcome," Nigerian Journal of Medicine, vol. 19, no. 1, pp. 14-21, 2010.

[64] M. Sasaki and T. Joh, "Oxidative stress and ischemia-reperfusion injury in gastrointestinal tract and antioxidant, protective agents," Journal of Clinical Biochemistry and Nutrition, vol. 40, no. 1, pp. 1-12, 2007.

[65] H. Khastar, M. Kadkhodaee, H. R. Sadeghipour et al., "Liver oxidative stress after renal ischemia-reperfusion injury is leukocyte dependent in inbred mice," Iranian Journal of Basic Medical Sciences, vol. 14, no. 6, pp. 534-539, 2011.

[66] S. Bereswill, M. Muñoz, A. Fischer et al., "Anti-inflammatory effects of resveratrol, curcumin and simvastatin in acute small intestinal inflammation," PLOS ONE, vol. 5, no. 12, Article ID e15099, 2010.

[67] C. T. Wu, H. P. Yu, C. Y. Chung, Y. T. Lau, and S. K. Liao, "Attenuation of lung inflammation and pro-inflammatory cytokine production by resveratrol following trauma-hemorrhage," The Chinese journal of physiology, vol. 51, no. 6, pp. 363-368, 2008.

[68] S. Dernek, M. Ikizler, N. Erkasap et al., "Cardioprotection with resveratrol pretreatment: improved beneficial effects over standard treatment in rat hearts after global ischemia," Scandinavian Cardiovascular Journal, vol. 38, no. 4, pp. 245-254, 2004.

[69] V. Sharma, R. M. Bell, and D. M. Yellon, “Targeting reperfusion injury in acute myocardial infarction: a review of reperfusion injury pharmacotherapy," Expert Opinion on Pharmacotherapy, vol. 13, no. 8, pp. 1153-1175, 2012.

[70] E. Dongó, I. Hornyák, Z. Benko, and L. Kiss, “The cardioprotective potential of hydrogen sulfide in myocardial ischemia/reperfusion injury (review)," Acta Physiologica Hungarica, vol. 98, no. 4, pp. 369-381, 2011.

[71] S. K. Powers, Z. Murlasits, M. Wu, and A. N. Kavazis, "Ischemiareperfusion-induced cardiac injury: a brief review," Medicine \& Science in Sports \& Exercise, vol. 39, no. 9, pp. 1529-1536, 2007.

[72] A. Movahed, L. Yu, S. J. Thandapilly, X. L. Louis, and T. Netticadan, "Resveratrol protects adult cardiomyocytes against oxidative stress mediated cell injury," Archives of Biochemistry and Biophysics, vol. 527, no. 2, pp. 74-80, 2012.

[73] S. Bradamante, L. Barenghi, and A. Villa, "Cardiovascular protective effects of resveratrol," Cardiovascular Drug Reviews, vol. 22, no. 3, pp. 169-188, 2004.

[74] Y. Tang, J. Xu, W. Qu et al., "Resveratrol reduces vascular cell senescence through attenuation of oxidative stress by SIRT1/NADPH oxidase-dependent mechanisms," Journal of Nutritional Biochemistry, vol. 23, no. 11, pp. 1410-1416, 2012.
[75] C.-L. Kao, L.-K. Chen, Y.-L. Chang et al., "Resveratrol protects human endothelium from $\mathrm{H}_{2} \mathrm{O}_{2}$-induced oxidative stress and senescence via SirT1 activation," Journal of Atherosclerosis and Thrombosis, vol. 17, no. 9, pp. 970-979, 2010.

[76] Y. Zheng, Y. Liu, J. Ge et al., "Resveratrol protects human lens epithelial cells against $\mathrm{H}_{2} \mathrm{O}_{2}$-induced oxidative stress by increasing catalase, SOD-1, and HO-1 expression," Molecular Vision, vol. 16, pp. 1467-1474, 2010.

[77] B. Wang, Q. Yang, Y. Y. Sun et al., "Resveratrol-enhanced autophagic flux ameliorates myocardial oxidative stress injury in diabetic mice," Journal of Cellular and Molecular Medicine, vol. 18, no. 8, pp. 1599-1611, 2014.

[78] G. Spanier, H. Xu, N. Xia et al., "Resveratrol reduces endothelial oxidative stress by modulating the gene expression of superoxide dismutase 1 (SOD1), glutathione peroxidase 1 (GPxl) and NADPH oxidase subunit (Nox4)," Journal of Physiology and Pharmacology, vol. 60, supplement 4, pp. 111-116, 2009.

[79] P.-W. Cheng, W.-Y. Ho, Y.-T. Su et al., "Resveratrol decreases fructose-induced oxidative stress, mediated by NADPH oxidase via an AMPK-dependent mechanism," British Journal of Pharmacology, vol. 171, no. 11, pp. 2739-2750, 2014.

[80] M. Mokni, S. Hamlaoui, I. Karkouch et al., "Resveratrol provides cardioprotection after ischemia/reperfusion injury via modulation of antioxidant enzyme activities," Iranian Journal of Pharmaceutical Research, vol. 12, no. 4, pp. 867-875, 2013.

[81] M. Shen, R.-X. Wu, L. Zhao et al., "Resveratrol attenuates ischemia/reperfusion injury in neonatal cardiomyocytes and its underlying mechanism," PLoS ONE, vol. 7, no. 12, Article ID e51223, 2012.

[82] M. Mokni, F. Limam, S. Elkahoui, M. Amri, and E. Aouani, "Strong cardioprotective effect of resveratrol, a red wine polyphenol, on isolated rat hearts after ischemia/reperfusion injury," Archives of Biochemistry and Biophysics, vol. 457, no. 1, pp. 1-6, 2007.

[83] M. Mohammadshahi, F. Haidari, and F. G. Soufi, "Chronic resveratrol administration improves diabetic cardiomyopathy in part by reducing oxidative stress," Cardiology Journal, vol. 21, no. 1, pp. 39-46, 2014.

[84] P. Toth, S. Tarantini, Z. Tucsek et al., "Resveratrol treatment rescues neurovascular coupling in aged mice: role of improved cerebromicrovascular endothelial function and downregulation of NADPH oxidase," American Journal of Physiology: Heart and Circulatory Physiology, vol. 306, no. 3, pp. H299-H308, 2014.

[85] E. Miller, A. Morel, L. Saso, and J. Saluk, "Isoprostanes and neuroprostanes as biomarkers of oxidative stress in neurodegenerative diseases," Oxidative Medicine and Cellular Longevity, vol. 2014, Article ID 572491, 10 pages, 2014.

[86] X. Qiao, J. Xu, Q.-J. Yang et al., “Transient acidosis during early reperfusion attenuates myocardium ischemia reperfusion injury VIA PI3K-AKT-eNOS signaling pathway," Oxidative Medicine and Cellular Longevity, vol. 2013, Article ID 126083, 6 pages, 2013.

[87] T. Wang, X. Mao, H. Li et al., "N-Acetylcysteine and allopurinol up-regulated the Jak/STAT3 and PI3K/Akt pathways via adiponectin and attenuated myocardial postischemic injury in diabetes," Free Radical Biology and Medicine, vol. 63, pp. 291303, 2013.

[88] L.-M. Hung, M.-J. Su, and J.-K. Chen, "Resveratrol protects myocardial ischemia-reperfusion injury through both NOdependent and NO-independent mechanisms," Free Radical Biology and Medicine, vol. 36, no. 6, pp. 774-781, 2004. 
[89] M. Lagouge, C. Argmann, Z. Gerhart-Hines et al., "Resveratrol improves mitochondrial function and protects against metabolic disease by activating SIRT1 and PGC-1 $\alpha$," Cell, vol. 127, no. 6, pp. 1109-1122, 2006.

[90] M. Shalwala, S.-G. Zhu, A. Das, F. N. Salloum, L. Xi, and R. C. Kukreja, "Sirtuin 1 (SIRT1) activation mediates sildenafil induced delayed cardioprotection against ischemia-reperfusion injury in mice," PLoS ONE, vol. 9, no. 1, Article ID e86977, 2014.

[91] S. Shigematsu, S. Ishida, M. Hara et al., "Resveratrol, a red wine constituent polyphenol, prevents superoxide-dependent inflammatory responses induced by ischemia/reperfusion, platelet-activating factor, or oxidants," Free Radical Biology and Medicine, vol. 34, no. 7, pp. 810-817, 2003.

[92] H. Li, Z. Yan, J. Zhu, J. Yang, and J. He, "Neuroprotective effects of resveratrol on ischemic injury mediated by improving brain energy metabolism and alleviating oxidative stress in rats," Neuropharmacology, vol. 60, no. 2-3, pp. 252-258, 2011.

[93] X. M. Zhou, M. L. Zhou, X. S. Zhang, Z. Zhuang, T. Li, and J. X. Shi, "Resveratrol prevents neuronal apoptosis in an early brain injury model," Journal of Surgical Research, vol. 189, no. 1, pp. 159-165, 2014.

[94] J. W. Gatson, M.-M. Liu, K. Abdelfattah et al., "Resveratrol decreases inflammation in the brain of mice with mild traumatic brain injury," Journal of Trauma and Acute Care Surgery, vol. 74, no. 2, pp. 470-475, 2013.

[95] F. Karalis, V. Soubasi, T. Georgiou et al., "Resveratrol ameliorates hypoxia/ischemia-induced behavioral deficits and brain injury in the neonatal rat brain," Brain Research, vol. 1425, pp. 98-110, 2011.

[96] K. Sinha, G. Chaudhary, and Y. Kumar Gupta, "Protective effect of resveratrol against oxidative stress in middle cerebral artery occlusion model of stroke in rats," Life Sciences, vol. 71, no. 6, pp. 655-665, 2002.

[97] S.-K. Tsai, L.-M. Hung, Y.-T. Fu et al., "Resveratrol neuroprotective effects during focal cerebral ischemia injury via nitric oxide mechanism in rats," Journal of Vascular Surgery, vol. 46, no. 2, pp. 346-353, 2007.

[98] E. Barocelli, V. Ballabeni, P. Ghizzardi et al., "The selective inhibition of inducible nitric oxide synthase prevents intestinal ischemia-reperfusion injury in mice," Nitric Oxide-Biology and Chemistry, vol. 14, no. 3, pp. 212-218, 2006.

[99] P. Orsu, B. V. S. N. Murthy, and A. Akula, "Cerebroprotective potential of resveratrol through anti-oxidant and antiinflammatory mechanisms in rats," Journal of Neural Transmission, vol. 120, no. 8, pp. 1217-1223, 2013.

[100] F. Simão, A. Matté, A. S. Pagnussat, C. A. Netto, and C. G. Salbego, "Resveratrol preconditioning modulates inflammatory response in the rat hippocampus following global cerebral ischemia," Neurochemistry International, vol. 61, no. 5, pp. 659665, 2012.

[101] U. Kiziltepe, N. N. D. Turan, U. Han, A. T. Ulus, and F. Akar, "Resveratrol, a red wine polyphenol, protects spinal cord from ischemia-reperfusion injury," Journal of Vascular Surgery, vol. 40, no. 1, pp. 138-145, 2004.

[102] H. S. Ozacmak, V. H. Ozacmak, F. Barut, M. Arasli, and B. H. Ucan, "Pretreatment with mineralocorticoid receptor blocker reduces intestinal injury induced by ischemia and reperfusion: involvement of inhibition of inflammatory response, oxidative stress, nuclear factor $\kappa \mathrm{B}$, and inducible nitric oxide synthase," Journal of Surgical Research, vol. 191, no. 2, pp. 350-361, 2014.
[103] J. Cui, L. Liu, J. Zou et al., "Protective effect of endogenous hydrogen sulfide against oxidative stress in gastric ischemiareperfusion injury," Experimental and Therapeutic Medicine, vol. 5, no. 3, pp. 689-694, 2013.

[104] P. R. Bertoletto, A. T. Ikejiri, F. S. Neto et al., "Oxidative stress gene expression profile in inbred mouse after ischemia/reperfusion small bowel injury," Acta Cirurgica Brasileira, vol. 27, no. 11, pp. 772-782, 2012.

[105] F. Yildiz, A. Terzi, S. Coban et al., "Protective effects of resveratrol on small intestines against intestinal ischemia-reperfusion injury in rats," Journal of Gastroenterology and Hepatology, vol. 24, no. 11, pp. 1781-1785, 2009.

[106] H. Namazi, "A novel molecular mechanism to account for the action of resveratrol against reperfusion injury," Annals of Vascular Surgery, vol. 22, no. 3, p. 492, 2008.

[107] A. B. Karabulut, V. Kirimlioglu, H. Kirimlioglu, S. Yilmaz, B. Isik, and O. Isikgil, "Protective effects of resveratrol on spleen and ileum in rats subjected to ischemia-reperfusion," Transplantation Proceedings, vol. 38, no. 2, pp. 375-377, 2006.

[108] L. Phillips, A. H. Toledo, F. Lopez-Neblina, R. Anaya-Prado, and L. H. Toledo-Pereyra, "Nitric oxide mechanism of protection in ischemia and reperfusion injury," Journal of Investigative Surgery, vol. 22, no. 1, pp. 46-55, 2009.

[109] M. Yamaguchi and M. Uchida, “ $\alpha$-Lactalbumin suppresses interleukin-6 release after intestinal ischemia/reperfusion via nitric oxide in rats," Inflammopharmacology, vol. 15, no. 1, pp. 43-47, 2007.

[110] L. Gu, N. Li, W. Yu et al., "Berberine reduces rat intestinal tight junction injury induced by ischemia-reperfusion associated with the suppression of inducible nitric oxide synthesis," The American Journal of Chinese Medicine, vol. 41, no. 6, pp. 12971312, 2013.

[111] M. Y. Kim, J. H. Lim, H. H. Youn et al., "Resveratrol prevents renal lipotoxicity and inhibits mesangial cell glucotoxicity in a manner dependent on the AMPK-SIRT1-PGC1 $\alpha$ axis in $\mathrm{db} / \mathrm{db}$ mice," Diabetologia, vol. 56, no. 1, pp. 204-217, 2013.

[112] G. Şener, H. Tuğtepe, M. Yüksel, Ş. Çetinel, N. Gedik, and B. Ç. Yeğen, "Resveratrol improves ischemia/reperfusion-induced oxidative renal injury in rats," Archives of Medical Research, vol. 37, no. 7, pp. 822-829, 2006.

[113] L. Giovannini, M. Migliori, B. M. Longoni et al., "Resveratrol, a polyphenol found in wine, reduces ischemia reperfusion injury in rat kidneys," Journal of Cardiovascular Pharmacology, vol. 37, no. 3, pp. 262-270, 2001.

[114] X. Fu, S. Li, G. Jia et al., "Protective effect of the nitric oxide pathway in L-citrulline renal ichaemia-reperfusion injury in rats," Folia Biologica, vol. 59, no. 6, pp. 225-232, 2013.

[115] A. Korkmaz and D. Kolankaya, "Inhibiting inducible nitric oxide synthase with rutin reduces renal ischemia/reperfusion injury," Canadian Journal of Surgery, vol. 56, no. 1, pp. 6-14, 2013.

[116] R. Schneider, M. Meusel, B. Betz et al., "Nitric oxideinduced regulation of renal organic cation transport after renal ischemia-reperfusion injury," The American Journal of Physiology-Renal Physiology, vol. 301, no. 5, pp. F997-F1004, 2011.

[117] V. Chander and K. Chopra, "Role of nitric oxide in resveratrolinduced renal protective effects of ischemic preconditioning," Journal of Vascular Surgery, vol. 42, no. 6, pp. 1198-1205, 2005.

[118] L. Y. Guan, P. Y. Fu, P. D. Li et al., "Mechanisms of hepatic ischemia-reperfusion injury and protective effects of nitric oxide," World Journal of Gastrointestinal Surgery, vol. 6, no. 7, pp. 122-128, 2014. 
[119] G. K. Glantzounis, H. J. Salacinski, W. Yang, B. R. Davidson, and A. M. Seifalian, "The contemporary role of antioxidant therapy in attenuating liver ischemia-reperfusion injury: a review," Liver Transplantation, vol. 11, no. 9, pp. 1031-1047, 2005.

[120] F.-C. Liu, Y.-F. Tsai, and H.-P. Yu, "Maraviroc attenuates traumahemorrhage-induced hepatic injury through PPAR gammadependent pathway in rats," PLOS ONE, vol. 8, no. 10, Article ID e78861, 2013.

[121] E. Gedik, S. Girgin, H. Ozturk, B. D. Obay, H. Ozturk, and H. Buyukbayram, "Resveratrol attenuates oxidative stress and histological alterations induced by liver ischemia/reperfusion in rats," World Journal of Gastroenterology, vol. 14, no. 46, pp. 71017106, 2008.

[122] S. Hassan-Khabbar, M. Vamy, C.-H. Cottart et al., "Protective effect of post-ischemic treatment with trans-resveratrol on cytokine production and neutrophil recruitment by rat liver," Biochimie, vol. 92, no. 4, pp. 405-410, 2010.

[123] S. Gennai, C. Pison, and R. Briot, "Ischemia-reperfusion injury after lung transplantation," La Presse Médicale, vol. 43, no. 9, pp. 921-930, 2014.

[124] J. Rong, S. Ye, M.-Y. Liang et al., "Receptor for advanced glycation end products involved in lung ischemia reperfusion injury in cardiopulmonary bypass attenuated by controlled oxygen reperfusion in a canine model," ASAIO Journal, vol. 59, no. 3, pp. 302-308, 2013.

[125] R. Campos, M. H. M. Shimizu, R. A. Volpini et al., "Nacetylcysteine prevents pulmonary edema and acute kidney injury in rats with sepsis submitted to mechanical ventilation," American Journal of Physiology-Lung Cellular and Molecular Physiology, vol. 302, no. 7, pp. L640-L650, 2012.

[126] D. Y.-W. Yeh, Y. H. Fu, Y.-C. Yang, and J.-J. Wang, "Resveratrol alleviates lung ischemia and reperfusion-induced pulmonary capillary injury through modulating pulmonary mitochondrial metabolism," Transplantation Proceedings, vol. 46, no. 4, pp. 1131-1134, 2014.

[127] S. Çayan, B. Saylam, N. Tiftik et al., "Rho-kinase levels in testicular ischemia-reperfusion injury and effects of its inhibitor, Y-27632, on oxidative stress, spermatogenesis, and apoptosis," Urology, vol. 83, no. 3, pp. 675-678, 2014.

[128] S. M. Wei, Z. Z. Yan, and J. Zhou, "Protective effect of rutin on testicular ischemia-reperfusion injury," Journal of Pediatric Surgery, vol. 46, no. 7, pp. 1419-1424, 2011.

[129] D. Y. Woodruff, G. Horwitz, J. Weigel, and A. K. Nangia, "Fertility preservation following torsion and severe ischemic injury of a solitary testis," Fertility and Sterility, vol. 94, no. 1, pp. 352-355, 2010.

[130] H. Yildiz, A. S. Durmus, H. Şimşek, and M. Yaman, "Protective effect of sildenafil citrate on contralateral testis injury after unilateral testicular torsion/detorsion," Clinics, vol. 66, no. 1, pp. 137-142, 2011.

[131] R. M. Vigueras, G. Reyes, J. Rojas-Castañeda, P. Rojas, and R. Hernández, "Testicular torsion and its effects on the spermatogenic cycle in the contralateral testis of the rat," Laboratory Animals, vol. 38, no. 3, pp. 313-320, 2004.

[132] B. Etensel, S. Özkisacik, E. Özkara et al., "Dexpanthenol attenuates lipid peroxidation and testicular damage at experimental ischemia and reperfusion injury," Pediatric Surgery International, vol. 23, no. 2, pp. 177-181, 2007.

[133] C. T. Ribeiro, R. Milhomem, D. B. De Souza, W. S. Costa, F. J. B. Sampaio, and M. A. Pereira-Sampaio, "Effect of antioxidants on outcome of testicular torsion in rats of different ages," Journal of Urology, vol. 191, no. 5, pp. 1578-1584, 2014.
[134] H. G. Piper, S. C. Oltmann, L. Xu, S. Adusumilli, and A. C. Fischer, "Ovarian torsion: diagnosis of inclusion mandates earlier intervention," Journal of Pediatric Surgery, vol. 47, no. 11, pp. 2071-2076, 2012.

[135] S. Krishnan, H. Kaur, J. Bali, and K. Rao, "Ovarian torsion in infertility management-missing the diagnosis means losing the ovary: a high price to pay," Journal of Human Reproductive Sciences, vol. 4, no. 1, pp. 39-42, 2011.

[136] H. Jaeschke, "Xanthine oxidase-induced oxidant stress during hepatic ischemia-reperfusion: are we coming full circle after 20 years?" Hepatology, vol. 36, no. 3, pp. 761-763, 2002.

[137] P. E. Canas, "The role of xanthine oxidase and the effects of antioxidants in ischemia reperfusion cell injury," Acta Physiologica Pharmacologica et Therapeutica Latinoamericana, vol. 49, no. 1, pp. 13-20, 1999.

[138] T. A. Johnson, N. A. Stasko, J. L. Matthews et al., "Reduced ischemia/reperfusion injury via glutathione-initiated nitric oxide-releasing dendrimers," Nitric Oxide-Biology and Chemistry, vol. 22, no. 1, pp. 30-36, 2010.

[139] H. J. Stein, M. M. J. Oosthuizen, R. A. Hinder, and H. Lamprechts, "Oxygen free radicals and glutathione in hepatic ischemia/reperfusion injury," Journal of Surgical Research, vol. 50, no. 4, pp. 398-402, 1991.

[140] S. Hascalik, O. Celik, Y. Turkoz et al., "Resveratrol, a red wine constituent polyphenol, protects from ischemia-reperfusion damage of the ovaries," Gynecologic and Obstetric Investigation, vol. 57, no. 4, pp. 218-223, 2004.

[141] M. He, H. Pan, R. C.-C. Chang, K.-F. So, N. C. Brecha, and $\mathrm{M} . \mathrm{Pu}$, "Activation of the Nrf2/HO-1 antioxidant pathway contributes to the protective effects of lycium barbarum polysaccharides in the rodent retina after ischemia-reperfusioninduced damage," PLoS ONE, vol. 9, no. 1, Article ID e84800, 2014.

[142] N. Dilsiz, A. Sahaboglu, M. Z. Yildiz, and A. Reichenbach, "Protective effects of various antioxidants during ischemiareperfusion in the rat retina," Graefe's Archive for Clinical and Experimental Ophthalmology, vol. 244, no. 5, pp. 627-633, 2006.

[143] O. Lewden, C. Garcher, C. Morales, A. Javouhey, L. Rochette, and A. M. Bron, "Changes of catalase activity after ischemiareperfusion in rat retina," Ophthalmic Research, vol. 28, no. 6, pp. 331-335, 1996.

[144] M. E. Szabo, M. T. Droy-Lefaix, M. Doly, and P. Braquet, "Modification of ischemia/reperfusion-induced ion shifts $\left(\mathrm{Na}^{+}\right.$, $\mathrm{K}^{+}, \mathrm{Ca}^{2+}$ and $\mathrm{Mg}^{2+}$ ) by free radical scavengers in the rat retina," Ophthalmic Research, vol. 25, no. 1, pp. 1-9, 1993.

[145] A. P. Vin, H. Hu, Y. Zhai et al., "Neuroprotective effect of resveratrol prophylaxis on experimental retinal ischemic injury," Experimental Eye Research, vol. 108, pp. 72-75, 2013.

[146] C. Li, L. Wang, K. Huang, and L. Zheng, "Endoplasmic reticulum stress in retinal vascular degeneration: protective role of resveratrol," Investigative Ophthalmology \& Visual Science, vol. 53, no. 6, pp. 3241-3249, 2012.

[147] D. Gao, X. Zhang, X. Jiang et al., "Resveratrol reduces the elevated level of MMP-9 induced by cerebral ischemia-reperfusion in mice," Life Sciences, vol. 78, no. 22, pp. 2564-2570, 2006.

[148] M. H. Sun, J. H. Pang, S. L. Chen et al., "Photoreceptor protection against light damage by AAV-mediated overexpression of heme oxygenase-1," Investigative Ophthalmology \& Visual Science, vol. 48, no. 12, pp. 5699-5707, 2007.

[149] X. Q. Liu, B. J. Wu, W. H. Pan et al., "Resveratrol mitigates rat retinal ischemic injury: the roles of matrix metalloproteinase-9, 
inducible nitric oxide, and heme oxygenase-1," Journal of Ocular Pharmacology and Therapeutics, vol. 29, no. 1, pp. 33-40, 2013.

[150] H. Yagmurdur, N. Ozcan, F. Dokumaci, K. Kilinc, F. Yilmaz, and H. Basar, "Dexmedetomidine reduces the ischemia-reperfusion injury markers during upper extremity surgery with tourniquet," Journal of Hand Surgery, vol. 33, no. 6, pp. 941-947, 2008.

[151] W. R. Carroll and R. M. Esclamado, "Ischemia/reperfusion injury in microvascular surgery," Head \& Neck, vol. 22, no. 7, pp. 700-713, 2000.

[152] M. Mathru, D. J. Dries, L. Barnes, P. Tonino, R. Sukhani, and M. W. Rooney, "Tourniquet-induced exsanguination in patients requiring lower limb surgery: an ischemia-reperfusion model of oxidant and antioxidant metabolism," Anesthesiology, vol. 84, no. 1, pp. 14-22, 1996.

[153] A. Lejay, A. Meyer, A.-I. Schlagowski et al., "Mitochondria: mitochondrial participation in ischemia-reperfusion injury in skeletal muscle," The International Journal of Biochemistry and Cell Biology, vol. 50, no. 1, pp. 101-105, 2014.

[154] S. Gillani, J. Cao, T. Suzuki, and D. J. Hak, "The effect of ischemia reperfusion injury on skeletal muscle," Injury, vol. 43, no. 6, pp. 670-675, 2012.

[155] H. T. Hua, H. Al-Badawi, F. Entabi et al., "CXC chemokine expression and synthesis in skeletal muscle during ischemia/reperfusion," Journal of Vascular Surgery, vol. 42, no. 2, pp. 337-343, 2005.

[156] A. Kadambi and T. C. Skalak, "Role of leukocytes and tissuederived oxidants in short-term skeletal muscle ischemiareperfusion injury," The American Journal of Physiology-Heart and Circulatory Physiology, vol. 278, no. 2, pp. H435-H443, 2000.

[157] M. Ikizler, C. Ovali, S. Dernek et al., "Protective effects of resveratrol in ischemia-reperfusion injury of skeletal muscle: a clinically relevant animal model for lower extremity ischemia," The Chinese Journal of Physiology, vol. 49, no. 4, pp. 204-209, 2006.

[158] N. Elmali, I. Esenkaya, N. Karadağ, and F. Taş, "Effects of resveratrol on skeletal muscle in ischemia-reperfusion injury," Ulusal Travma ve Acil Cerrahi Dergisi, vol. 13, no. 4, pp. 274280, 2007.

[159] M. Nomiya, O. Yamaguchi, K.-E. Andersson et al., "The effect of atherosclerosis-induced chronic bladder ischemia on bladder function in the rat," Neurourology and Urodynamics, vol. 31, no. 1, pp. 195-200, 2012.

[160] A. Ali, G. Nabi, S. Swami, and B. Somani, "Bladder necrosis secondary to internal iliac artery embolization following pelvic fracture," Urology Annals, vol. 6, no. 2, pp. 166-168, 2014.

[161] G. E. Senturk, K. Erkanli, U. Aydin et al., "The protective effect of oxytocin on ischemia/reperfusion injury in rat urinary bladder," Peptides, vol. 40, pp. 82-88, 2013.

[162] Y.-S. Juan, S. M. Chuang, B. A. Kogan et al., "Effect of ischemia/reperfusion on bladder nerve and detrusor cell damage," International Urology and Nephrology, vol. 41, no. 3, pp. 513-521, 2009.

[163] A. Yildirim, F. F. Onol, G. Haklar, and T. Tarcan, "The role of free radicals and nitric oxide in the ischemia-reperfusion injury mediated by acute bladder outlet obstruction," International Urology and Nephrology, vol. 40, no. 1, pp. 71-77, 2008.

[164] H. Toklu, I. Alican, F. Ercan, and G. Sener, "The beneficial effect of resveratrol on rat bladder contractility and oxidant damage following ischemia/reperfusion," Pharmacology, vol. 78, no. 1 , pp. 44-50, 2006.
[165] H.-P. Yu, T.-L. Hwang, C.-H. Yen, and Y.-T. Lau, "Resveratrol prevents endothelial dysfunction and aortic superoxide production after trauma hemorrhage through estrogen receptordependent hemeoxygenase-1 pathway," Critical Care Medicine, vol. 38, no. 4, pp. 1147-1154, 2010.

[166] Z. F. Ba, J. F. Kuebler, L. W. Rue III, K. I. Bland, P. Wang, and I. H. Chaudry, "Gender dimorphic tissue perfusion response after acute hemorrhage and resuscitation: role of vascular endothelial cell function," The American Journal of Physiology-Heart and Circulatory Physiology, vol. 284, no. 6, pp. H2162-H2169, 2003.

[167] P. Wang, Z. F. Ba, and I. H. Chaudry, "Endothelial cell dysfunction occurs very early following trauma- hemorrhage and persists despite fluid resuscitation," American Journal of Physiology-Heart and Circulatory Physiology, vol. 265, no. 3, part 2, pp. H973-H979, 1993.

[168] H.-P. Yu, P.-W. Lui, T.-L. Hwang, C.-H. Yen, and Y.-T. Lau, "Propofol improves endothelial dysfunction and attenuates vascular superoxide production in septic rats," Critical Care Medicine, vol. 34, no. 2, pp. 453-460, 2006.

[169] L. Szalay, T. Shimizu, M. G. Schwacha et al., "Mechanism of salutary effects of estradiol on organ function after traumahemorrhage: upregulation of heme oxygenase," American Journal of Physiology-Heart and Circulatory Physiology, vol. 289, no. 1, pp. H92-H98, 2005.

[170] C.-C. Chang, C.-Y. Chang, J.-P. Huang, and L.-M. Hung, "Effect of resveratrol on oxidative and inflammatory stress in liver and spleen of streptozotocin-induced type 1 diabetic rats," The Chinese Journal of Physiology, vol. 55, no. 3, pp. 192-201, 2012.

[171] J. Li, L. Feng, Y. Xing et al., "Radioprotective and antioxidant effect of resveratrol in hippocampus by activating Sirt1," International Journal of Molecular Sciences, vol. 15, no. 4, pp. 59285939, 2014.

[172] B. Jian, S. Yang, I. H. Chaudry, and R. Raju, "Resveratrol improves cardiac contractility following trauma-hemorrhage by modulating Sirtl," Molecular Medicine, vol. 18, no. 2, pp. 209214, 2012.

[173] J. T. Hsu, H. C. Yeh, T. H. Chen et al., "Role of Akt/HO-1 pathway in estrogen-mediated attenuation of trauma-hemorrhageinduced lung injury," Journal of Surgical Research, vol. 182, no. 2, pp. 319-325, 2013.

[174] J.-T. Hsu, W.-H. Kan, C.-H. Hsieh et al., "Mechanism of estrogen-mediated intestinal protection following traumahemorrhage: p38 MAPK-dependent upregulation of HO-1," The American Journal of Physiology-Regulatory Integrative and Comparative Physiology, vol. 294, no. 6, pp. R1825-R1831, 2008.

[175] J.-T. Hsu, W.-H. Kan, C.-H. Hsieh, M. A. Choudhry, K. I. Bland, and I. H. Chaudry, "Mechanism of salutary effects of estrogen on cardiac function following trauma-hemorrhage: Akt-dependent HO-1 up-regulation," Critical Care Medicine, vol. 37, no. 8, pp. 2338-2344, 2009.

[176] H. P. Yu, M. A. Choudhry, T. Shimizu et al., "Mechanism of the salutary effects of flutamide on intestinal myeloperoxidase activity following trauma-hemorrhage: up-regulation of estrogen receptor- $\beta$-dependent HO-1," Journal of Leukocyte Biology, vol. 79, no. 2, pp. 277-284, 2006.

[177] D. He, X. Liu, Y. Pang, and L. Liu, "Inhibitory effect of resveratol on ischemia reperfusion-induced cardiocyte apoptosis and its relationship with PI3K-Akt signaling pathway," Zhongguo Zhong Yao Za Zhi, vol. 37, no. 15, pp. 2323-2326, 2012.

[178] Y.-F. Tsai, F.-C. Liu, Y.-T. Lau, and H.-P. Yu, "Role of Aktdependent pathway in resveratrol-mediated cardioprotection 
after trauma-hemorrhage," Journal of Surgical Research, vol. 176, no. 1, pp. 171-177, 2012.

[179] H.-P. Yu, S.-C. Yang, Y.-T. Lau, and T.-L. Hwang, "Role of Aktdependent up-regulation of hemeoxygenase-1 in resveratrolmediated attenuation of hepatic injury after trauma hemorrhage," Surgery, vol. 148, no. 1, pp. 103-109, 2010.

[180] F. C. Liu, Y. J. Day, C. H. Liao, J. T. Liou, C. C. Mao, and H. P. Yu, "Hemeoxygenase-1 upregulation is critical for sirtinol-mediated attenuation of lung injury after trauma-hemorrhage in a rodent model," Anesthesia and Analgesia, vol. 108, no. 6, pp. 1855-1861, 2009. 


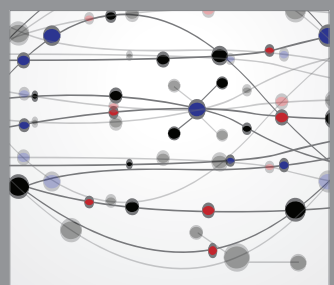

The Scientific World Journal
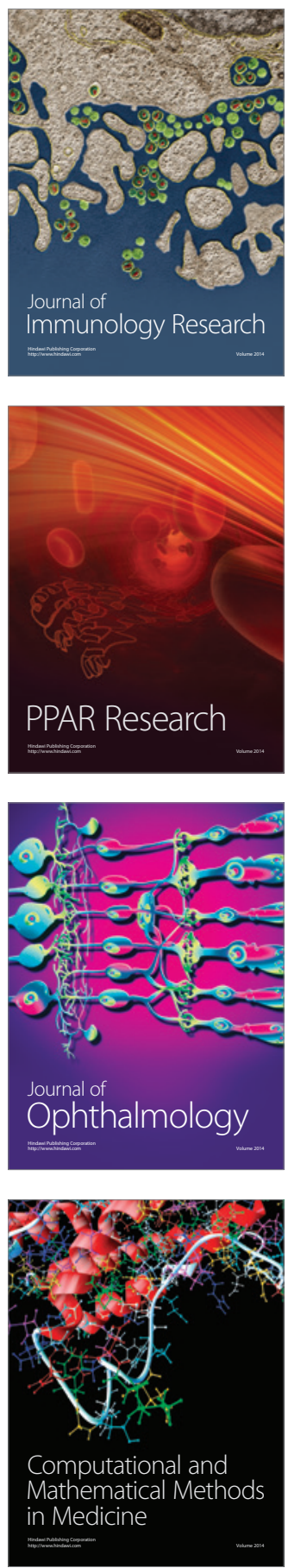

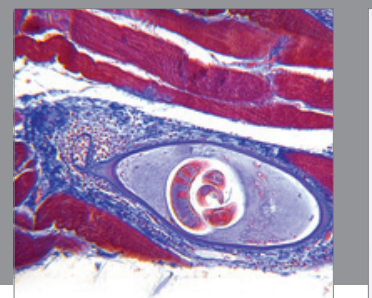

Gastroenterology

Research and Practice
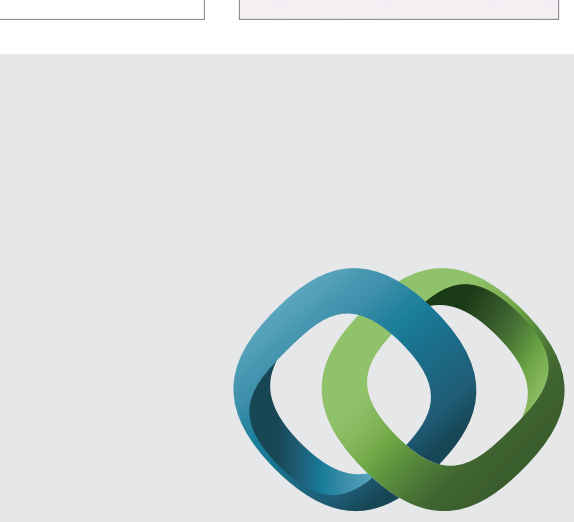

\section{Hindawi}

Submit your manuscripts at

http://www.hindawi.com
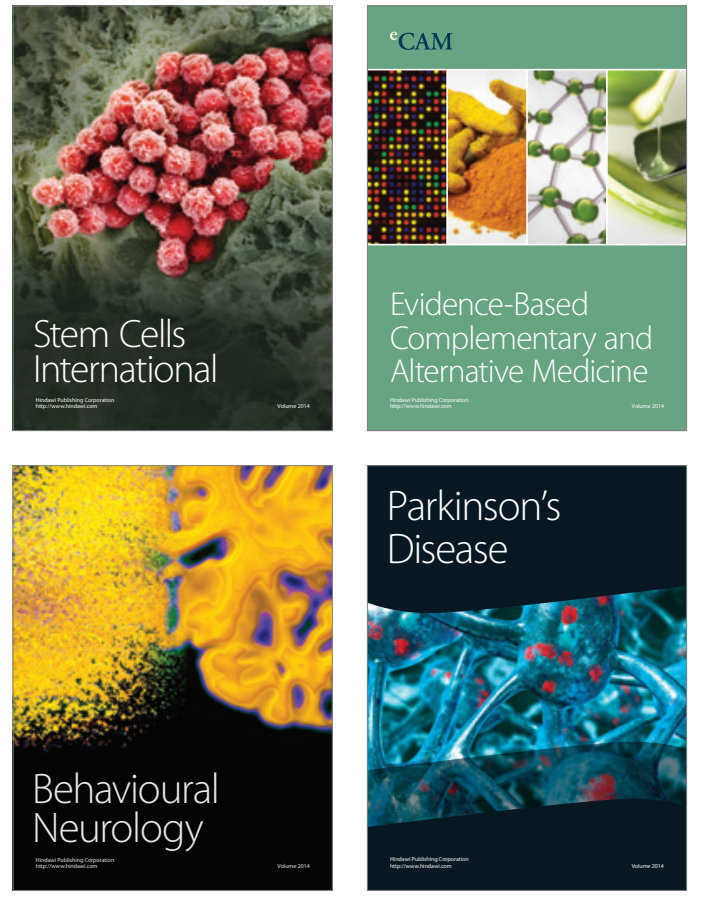
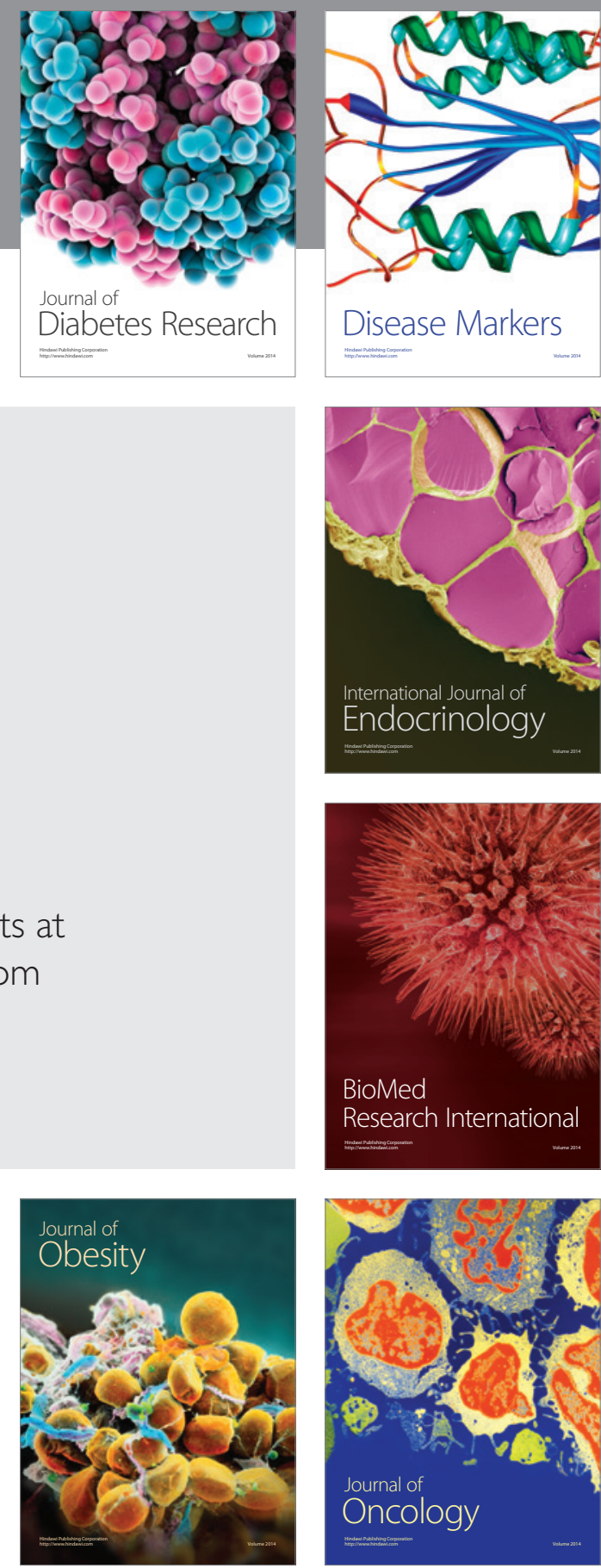

Disease Markers
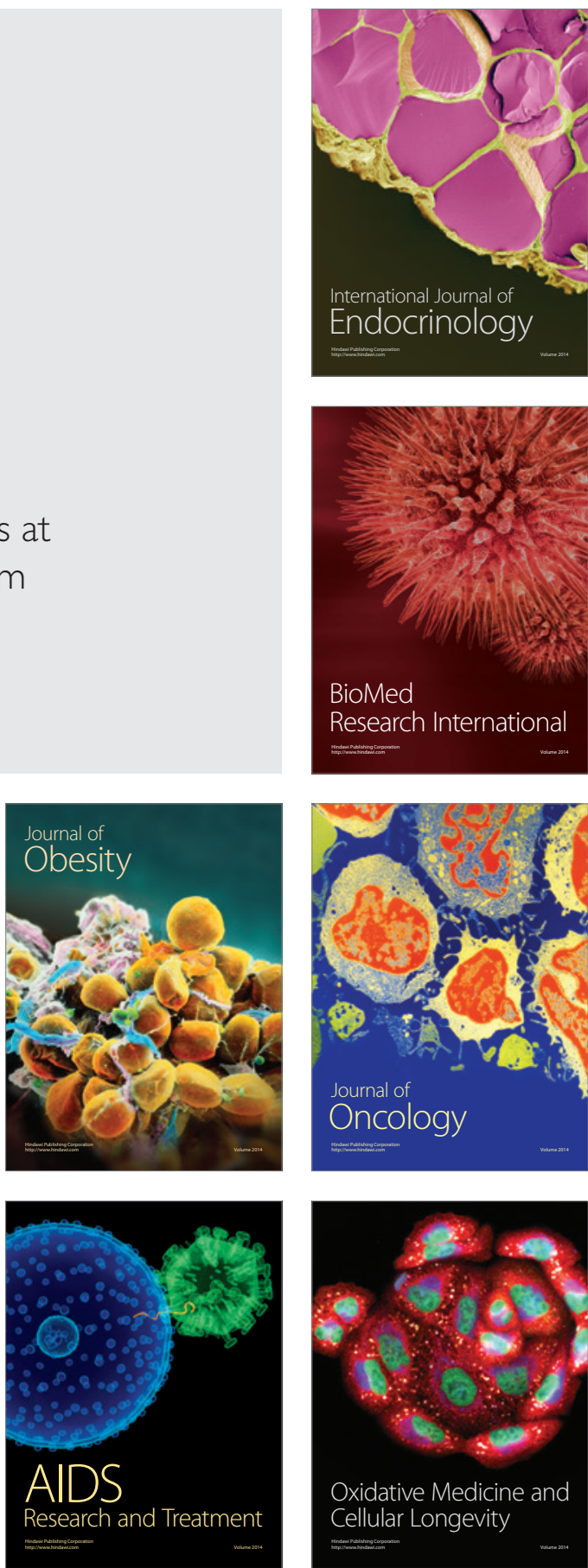